\title{
1,3-Butadiene: a ubiquitous environmental mutagen and its associations with diseases
}

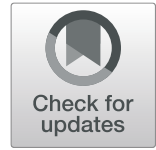

\author{
Wan-Qi Chen and Xin-Yu Zhang* (D)
}

\begin{abstract}
1,3-Butadiene (BD) is a petrochemical manufactured in high volumes. It is a human carcinogen and can induce lymphohematopoietic cancers, particularly leukemia, in occupationally-exposed workers. BD is an air pollutant with the major environmental sources being automobile exhaust and tobacco smoke. It is one of the major constituents and is considered the most carcinogenic compound in cigarette smoke. The BD concentrations in urban areas usually vary between 0.01 and $3.3 \mathrm{\mu g} / \mathrm{m}^{3}$ but can be significantly higher in some microenvironments. For BD exposure of the general population, microenvironments, particularly indoor microenvironments, are the primary determinant and environmental tobacco smoke is the main contributor. BD has high cancer risk and has been ranked the second or the third in the environmental pollutants monitored in most urban areas, with the cancer risks exceeding $10^{-5}$. Mutagenicity/carcinogenicity of $\mathrm{BD}$ is mediated by its genotoxic metabolites but the specific metabolite(s) responsible for the effects in humans have not been determined. BD can be bioactivated to yield three mutagenic epoxide metabolites by cytochrome P450 enzymes, or potentially be biotransformed into a mutagenic chlorohydrin by myeloperoxidase, a peroxidase almost specifically present in neutrophils and monocytes. Several urinary BD biomarkers have been developed, among which N-acetyl-S-(4-hydroxy-2-buten-1-yl)$\mathrm{L}$-cysteine is the most sensitive and is suitable for biomonitoring BD exposure in the general population. Exposure to BD has been associated with leukemia, cardiovascular disease, and possibly reproductive effects, and may be associated with several cancers, autism, and asthma in children. Collectively, BD is a ubiquitous pollutant that has been associated with a range of adverse health effects and diseases with children being a subpopulation with potentially greater susceptibility. Its adverse effects on human health may have been underestimated and more studies are needed.
\end{abstract}

Keywords: Butadiene, Environmental mutagen and carcinogen, Human exposure, Microenvironments, Urinary biomarkers, Cigarette smoking, Lung and larynx cancers, Adverse health effects, Children's health

\section{Introduction}

1,3-Butadiene (BD), a colorless gas, is an important petrochemical manufactured in high volumes that is primarily used to produce synthetic rubber and thermoplastic resins. BD is a ubiquitously environmental pollutant because it is formed as a product of incomplete combustion of fossil fuels and biomass [1]. It is

\footnotetext{
*Correspondence: xyzhang999@shsmu.edu.cn

School of Public Health, Hongqiao International Institute of Medicine,

Shanghai Jiao Tong University School of Medicine, Shanghai 200025, China
}

one of volatile organic compounds (VOCs) monitored routinely in the ambient air.

$\mathrm{BD}$ was determined to be a human carcinogen by the U.S. Environmental Protection Agency (EPA) in 2002 [1] and by the International Agency for Research on Cancer (IARC) in 2008 (Group 1 carcinogen) [2]. BD induces lymphohematopoietic cancers in occupationally-exposed workers [1, 2]. It is one of 187 hazardous air pollutants (HAPs), also known as air toxics, as defined by EPA [3].

BD was fully reviewed in the official document "Health Assessment of 1,3-Butadiene" issued by EPA in 2002 [1]

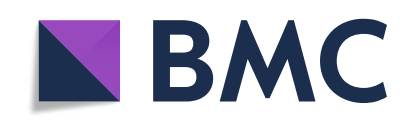

(c) The Author(s). 2022 Open Access This article is licensed under a Creative Commons Attribution 4.0 International License, which permits use, sharing, adaptation, distribution and reproduction in any medium or format, as long as you give appropriate credit to the original author(s) and the source, provide a link to the Creative Commons licence, and indicate if changes were made. The images or other third party material in this article are included in the article's Creative Commons licence, unless indicated otherwise in a credit line to the material. If material is not included in the article's Creative Commons licence and your intended use is not permitted by statutory regulation or exceeds the permitted use, you will need to obtain permission directly from the copyright holder. To view a copy of this licence, visit http://creativecommons.org/licenses/by/4.0/ The Creative Commons Public Domain Dedication waiver (http://creativecommons.org/publicdomain/zero/1.0/) applies to the data made available in this article, unless otherwise stated in a credit line to the data. 
and in Volume 97 of the IARC Monographs on the Evaluation of Carcinogenic Risks to Humans published in 2008 [2]. In the two documents, almost all aspects of BD were discussed in great detail. In 2012, IARC published Volume 100F and provided an update on BD based on newly available data [4]. In addition, the metabolism, DNA adducts, toxicology, genotoxicity, and the carcinogenic modes of action of $\mathrm{BD}$ were also reviewed in 2007 and 2010 [5-8]. However, since then many new studies, in particular, the epidemiological studies concerning the associations with several diseases in children, have been published but have not been reviewed yet. Thus, in this review, we will provide an update on major progress in BD-related studies over the last decade. However, we do not try to include all BD-related literature published during this period. Rather, we will focus on progress in the following aspects: environmental sources, airborne concentrations, human exposure, cancer risks, metabolism, urinary biomarkers, genotoxicity in humans, and associations with diseases. Additionally, because $\mathrm{BD}$ is one of the major constituents in tobacco smoke, we discuss the possible contribution of BD to tobacco smoking-associated diseases, with the focus being on cancers of lung and larynx.

\section{The environmental sources of BD}

BD has many environmental sources, including industrial emissions from production of $\mathrm{BD}$, rubber, and resins, automobile exhaust, tobacco smoke, and exhaust from biomass burning and cooking [1]. According to EPA, automobile exhaust and miscellaneous combustion sources contribute $78.8 \%$ and $19.6 \%$ of the total $\mathrm{BD}$ emissions in the environment, respectively. The industrial emissions account for only $1.6 \%$ of the total $\mathrm{BD}$ amounts in the environment, in spite of the fact that tremendous amounts of BD are produced and used in petrochemical and synthetic rubber industries [1].

Automobile exhaust is the primary source of $\mathrm{BD}$ in the environment due to the enormous amounts of fuels consumed by automobiles [1]. The average emission factor of vehicles was reported to be $2.1 \pm 1.5 \mathrm{mg} / \mathrm{km}$ in 1997 [9] and $0.7 \pm 0.4 \mathrm{mg} / \mathrm{km}$ in 2018 [10]. However, the emission factors are substantially greater in congested traffic compared with those under highway cruise conditions [11]. The BD emissions reduce when vehicles use fuels containing ethanol [12] but increase for biodiesel [13]. It has been estimated that on-road and nonroad motor vehicles contribute to $51 \%$ and $20 \%$ of the BD emissions in urban counties in the United States, respectively [14].

Cigarette smoke contains significant amounts of $\mathrm{BD}$ and can thus be the primary source in indoor air [1]. The yields of BD in cigarette smoke are 12-92 $\mu \mathrm{g} /$ cigarette in the mainstream smoke [15-17] and 205-361 $\mu \mathrm{g} /$ cigarette in the sidestream smoke [18]. Similarly, smoke of other tobacco products also contains BD. Bidi, an indigenous form of cigarette in South Asian countries, was reported to produce $63.8 \mu \mathrm{g} \mathrm{BD} /$ bidi in the mainstream smoke [19]. The $\mathrm{BD}$ yields in the mainstream smoke of 60 commercial U.S. little cigars vary from 46 to $243 \mu \mathrm{g} /$ cigar [20].

A source that may be important for certain microenvironments is smoke released by cooking oils at high temperature. It has been known that heating of cooking oil releases BD [1]. The BD levels released depend on the types of cooking oil and temperature [21, 22]. For example, the vapor of unrefined Chinese rapeseed oil heated to $275{ }^{\circ} \mathrm{C}$ contains $\sim 500 \mu \mathrm{g} / \mathrm{m}^{3}$ of $\mathrm{BD}$, which is 4- and 14-fold higher than that in the vapor generated at 240 and $185{ }^{\circ} \mathrm{C}$, respectively. This $\mathrm{BD}$ concentration is also 9- and 22-fold higher than that in the vapor released from heated soybean oil and peanut oil, respectively [21]. The smoke released during cooking Sichuan, Cantonese, and Shanghai cuisine contains BD at 12.87, 4.53 , and $4.20 \mu \mathrm{g} / \mathrm{m}^{3}$, respectively [23].

In recent years, many newly-identified sources have been reported, including emissions from oil and natural gas extraction industry [24], pyrolysis of waste plastics [25], pulp and paper industry [26], domestic waste landfill sites [27], household laser processing machines [28], and emissions from operations during electrosurgery [29-32], and from plants [33] and a soil bacterium species [34]. Among them, two types of sources are worth special attention. One of them is the surgical smoke generated during electrosurgery, which contains exceedingly high concentrations of BD (up to $42 \mathrm{mg} / \mathrm{m}^{3}$ or 19.06 ppm [29]) and thus may pose great cancer risks for operating room personnel [29-32]. The other is the natural sources; recently it was reported that BD was one of the dominant non-methane hydrocarbons generated by Pinus massoniana and Schima superba, two tree species native to southern China, with the emission rates varying from 10 to $65 \mathrm{nmol}(0.54$ to $3.5 \mu \mathrm{g}) / \mathrm{g}$ dry leaves/h [33]. $\mathrm{BD}$ was also reported to be generated by Bacillus artrophaeus LSSC22, a soil bacterium strain, and be able to inhibit proliferation and chemotaxis of Ralstonia solanacearum (Rsc) TBBS1, the phytopathogen causing bacterial wilt disease in tobacco [34]. These studies are the first reports on the natural sources of BD.

Because automobile exhaust contributes a majority of the $\mathrm{BD}$ emissions in the environment, $\mathrm{BD}$ is generally accepted as a mobile source pollutant or a traffic-related pollutant $[35,36]$. Nonetheless, several population-based studies have revealed that environmental tobacco smoke (ETS) is a primary contributor to human BD exposure (see below). In other words, ETS is the main source for the general population in terms of human exposure. The observation is important for epidemiological studies. 


\section{The airborne concentrations of $\mathrm{BD}$}

The $\mathrm{BD}$ concentrations in the ambient air vary widely and are dependent on locations or sites, which can be roughly divided into two categories: industrial/industryrelated sites and non-industrial sites. Obviously, the latter is more important for the general population.

Unsurprisingly, the BD concentrations at industrial and industry-related sites, e.g., sites close to industrial facilities, are usually higher in comparison with those at non-industrial sites [35]. For example, a maximal BD concentration of $27 \mathrm{ppb}\left(60 \mu \mathrm{g} / \mathrm{m}^{3}\right)$ was observed in a county downwind of a refinery facility in the Industrial Heartland of Alberta, Canada's largest hydrocarbon processing center [37]; an overall arithmetic mean of 120 $\mu \mathrm{g} / \mathrm{m}^{3}$ was reported for various industries in Italia during 1996-2015 [38]. Gallego et al. reported that the BD concentrations in a few Catalan urban areas in Spain near petrochemical facilities ranged from 15 to $33 \mu \mathrm{g} / \mathrm{m}^{3}$ [39]. A study to measure VOCs at 16 sampling sites in the North Industrial Complex of Tarragona, Spain, reported a BD range from 0.31 to $15.19 \mu \mathrm{g} / \mathrm{m}^{3}$ [40].

The $\mathrm{BD}$ concentrations at non-industrial sites vary greatly. Huy et al. compiled the BD concentrations in different countries and regions reported in the literature [41]. The average concentrations range from 0.01 to 3.3 $\mu \mathrm{g} / \mathrm{m}^{3}$, but the developed countries or regions (e.g., Hong Kong) have lower concentrations $\left(0.01-0.91 \mu \mathrm{g} / \mathrm{m}^{3}\right)$ compared to the developing countries $\left(0.35-3.3 \mu \mathrm{g} / \mathrm{m}^{3}\right)$ [41]. An EPA official document released in 2012 provided the range of the mean $\mathrm{BD}$ concentrations in U.S. cities and suburban areas, and the average background concentration, which were $0.1-2$ and $0.13 \mu \mathrm{g} / \mathrm{m}^{3}$, respectively [42]. The BD concentrations in rural areas $\left(0.002-0.125 \mu \mathrm{g} / \mathrm{m}^{3}\right)$ are typically one order of magnitude lower than those in urban areas $[35,41]$. Furthermore, in urban areas, the BD concentrations at commercial sites, particularly at sites close to the street level in the urban core, are usually higher than those at residential sites [35]. A modeling study of the BD concentrations in Minnesota, U.S., showed that the concentrations were the highest in the center of the metro area and decreased with distance from there [43]. Technological advances have led to significant decreases in the ambient air levels of BD and other VOCs in developed countries [35, 44-47].

However, in terms of human exposure, the BD concentrations in microenvironments, particularly indoor microenvironments, where people spend most of time, are more important than those in the ambient environment. Importantly, the $\mathrm{BD}$ concentrations in microenvironments are often unrelated to the ambient measurements at nearby monitors [48], which mostly reflect the BD concentrations in near-road environments [36]. A recent report also found that there was no association between ambient VOC levels, including BD, and personal exposures [44].
The BD concentrations in microenvironments vary widely depending on the proximity to emission sources and their magnitudes. Automobile exhaust and ETS are the major sources of $\mathrm{BD}$ at non-industrial sites, as a result, the microenvironments with these sources often show relatively high $\mathrm{BD}$ concentrations. Indeed, the roadside $\mathrm{BD}$ levels are usually higher than the background levels [14, 35, 36]. Exhaust from biomass burning is also an important source of $\mathrm{BD}$ in the environment, consequently, some special microenvironments with the source can have elevated BD levels. Temples are one of such microenvironments due to incense burning; an air BD concentration as high as 10.46 $\mu \mathrm{g} / \mathrm{m}^{3}$ inside three temples in Thailand has been reported [49]. Important microenvironments concerning human exposure include:

1) Vehicles. In a study to investigate the concentrations of VOCs in urban domestic and public microenvironments, Kim et al. found that the mean BD concentration in automobile was $7.9 \mu \mathrm{g} / \mathrm{m}^{3}$, which was the highest in all microenvironments examined [50]. Even the air surrounding moving vehicles contains relatively high concentrations of BD; a mean of $3.0 \mu \mathrm{g} / \mathrm{m}^{3}$ and a maximum of $6.9 \mu \mathrm{g} / \mathrm{m}^{3}$ have been reported [1].

2) Rooms with smoking. Cigarette smoke contains significant amounts of $\mathrm{BD}$, as a result, the $\mathrm{BD}$ concentrations in smoke-filled rooms can be high. An experiment, which was performed in a ventilated $18 \mathrm{~m}^{3}$ laboratory chamber with 6 cigarettes being smoked, showed that the BD concentrations were 122,34 , and $3.9 \mu \mathrm{g} / \mathrm{m}^{3}$ as measured at $20 \mathrm{~min}, 2 \mathrm{~h}$, and $18 \mathrm{~h}$ after smoking had ended, respectively [51]. Before a smoking ban was implemented in Ireland, the average BD concentration in pubs was reported to be $4.15 \mu \mathrm{g} / \mathrm{m}^{3}$ [52]. A mean BD concentration of $1.7 \mu \mathrm{g} / \mathrm{m}^{3}$ in smoking homes, which is 3.4 times higher than that in nonsmoking homes, has been reported [50].

3) Certain restaurants and kitchens. Recently, Huang et al. reported that the dining area in a Chinese hot-pot restaurant had a BD concentration of $7.73 \mu \mathrm{g} / \mathrm{m}^{3}$, probably due to the use of gas stoves [23]. Kitchens, especially those cooking Chinese cuisine by using hightemperature oils, can be a potential microenvironment with relatively high $\mathrm{BD}$ concentrations due to the $\mathrm{BD}$ release from heated oils.

4) Operating rooms. Because the surgical smoke generated during electrosurgery contains extremely high concentrations of BD [29], plus most surgeons do not use smoke management at all [30, 32] or the mobile smoke evacuation systems cannot effectively remove $\mathrm{BD}$ in the smoke [29], the operating rooms performing electrosurgery can be an indoor microenvironment with relatively high BD concentrations. 


\section{Human exposure to $B D$}

Human exposure to BD can be divided into two categories: occupational and non-occupational. Occupational exposure usually occurs at industrial sites, and the exposure levels are generally high but are dependent on the types of industry, activity sectors, and occupational groups. An investigation on Italian working force indicated that the exposure levels in most activity sectors or occupational groups ranged between 10 and $200 \mu \mathrm{g} / \mathrm{m}^{3}$, but the exposure levels in the manufacture of rubber and plastic products $\left(320-360 \mu \mathrm{g} / \mathrm{m}^{3}\right)$, and the manufacture of coke and refined petroleum products (340-390 $\mu \mathrm{g} / \mathrm{m}^{3}$ ) were significantly higher than those in other sectors [38]. The firm size can influence the exposure levels as well; micro- and small enterprises have greater probability to show higher exposure levels [38]. In a petrochemical plant in Iran, the $\mathrm{BD}$ exposure level reaches $560.82 \pm 811.36 \mu \mathrm{g} / \mathrm{m}^{3}$ [53]. However, technical advances and changes in the operating practices can greatly reduce the human exposure. For example, two studies published in 2016 and 2017 reported low exposure levels in the Swedish petroleum refinery industry, which varied from 0.3 to $22.4 \mu \mathrm{g} / \mathrm{m}^{3}$, depending on the occupational groups $[54,55]$. Similarly, a study published in 2017 reported that the BD exposure level in the vicinity of a major petrochemical complex in Thailand was as low as $0.04 \mu \mathrm{g} / \mathrm{m}^{3}$ [56].

Recently, some newly-identified occupations outside the common activity sectors are found to have low to moderate BD exposure levels, which include underground coal miners $\left(\sim 2.1 \mu \mathrm{g} / \mathrm{m}^{3}\right)$ [57], firefighters (23.6 $\left.\mu \mathrm{g} / \mathrm{m}^{3}\right)$, police forensic investigators $\left(9.68 \mu \mathrm{g} / \mathrm{m}^{3}\right)$ [58], and hairdressers [59]. It is noted that exposure of hairdressers to BD was assessed through the levels of urinary $\mathrm{BD}$ biomarkers rather than through measuring the airborne $\mathrm{BD}$ concentrations; the median concentration of a BD biomarker among hairdressers, who were all female, was found to be more than 5 times higher compared to women in the general population [59].

On the other hand, non-occupational exposure to $\mathrm{BD}$ is widespread and microenvironments can be the primary determinant. Because humans usually spend most of time indoors rather than outdoors, human exposure to BD is mainly dependent on the concentrations in indoor microenvironments. Kim et al. determined personal exposures of 12 urban dwellers to VOCs by direct measurements via personal monitoring and discovered that exposure at home contributed to $51-87 \%$ of overall individual exposure to BD [60]. Similarly, Huy et al. reported that exposure at home dominantly contributed to the total cancer risk caused by BD (56-86\%) [41]. In another study, Du et al. estimated that $\sim 70 \%$ of the overall cancer risks caused by 16 HAPs (including BD) in China was attributed to exposure to these pollutants at home
[61]. In a recent population study, Konkle et al. found that, although the ambient air concentrations of 11 VOCs in the United States, including BD, decreased from 2005 to 2013, all corresponding urinary metabolites of the VOCs increased over approximately the same timeframe except for one metabolite [44]. As pointed out by the authors, the finding indicated that these VOCs in the ambient air were not the major source of VOC exposure [44], thus providing indirect support for the role of microenvironments in exposure to $\mathrm{BD}$ and other VOCs.

For non-occupational exposure to BD, ETS can be a principal contributor. Measurements of the BD concentrations in indoor air before and after the implementation of a smoking ban in Ireland provide direct evidence of the contribution of ETS to the BD levels in indoor microenvironments. The airborne $\mathrm{BD}$ concentration prior to the implementation of the ban, which was 4.15 $\mu \mathrm{g} / \mathrm{m}^{3}$, dropped down by nearly 20 -fold to $0.22 \mu \mathrm{g} / \mathrm{m}^{3}$ after the ban was fully implemented [52].

As mentioned above, BD is generally considered an automobile source pollutant or a traffic-related pollutant, however, the results from several population studies suggest that human exposure to $\mathrm{BD}$ is mostly attributed to ETS. In a study to investigate biological monitoring of exposures to ETS in the general population, Aquilina et al. observed that urinary concentration of cotinine, a well-known ETS biomarker, showed significant correlation with the individual exposure to airborne $\mathrm{BD}$ that was measured with personal exposure samplers [62]. The finding suggests that ETS is a significant source of exposure to BD for the general population. In a study assessing exposure to VOCs among pregnant women in the United States, Boyle et al. found that smoking was positively associated with the metabolite levels of $\mathrm{BD}$ [63]. The results obtained from a recent study on nearly 6,000 participants indicated that tobacco smoke was a major source of BD exposure in the general U.S. population [64]. These reports are consistent with the evaluation for residential exposures of U.S. nonsmokers based on material-balance modeling; the evaluation indicated that ETS was the dominant source of environmental inhalation intake for $\mathrm{BD}$, which was estimated to be 16-37 $\mu \mathrm{g} /$ day [65]. Taken together, for the general population, it appears that the indoor microenvironments are the dominant factor in human exposure to $\mathrm{BD}$, and ETS is the primary source of $\mathrm{BD}$ in these microenvironments.

A special microenvironment that might lead to relatively high exposure to $\mathrm{BD}$ is kitchens with the cooking practice using high-temperature oils. However, the studies concerning the microenvironment have been extremely scarce. Using the levels of urinary biomarkers as the metric to assess exposure to VOCs, an investigation 
on Chinese women who regularly cook at home has failed to provide support for the women to experience elevated BD exposure. However, the size of the study is quite small and many confounders can have influenced the outcome [66].

Interestingly, exposure to $\mathrm{BD}$ was found to be dependent on socio-demographic characteristics. The populations with a high percentage of ethnic/racial minorities and low income tend to have higher exposure levels [67].

\section{The cancer risks of BD}

$\mathrm{BD}$ has high cancer risks. The inhalation unit cancer risk determined by EPA is $3 \times 10^{-5}$ per $\mu \mathrm{g} / \mathrm{m}^{3}$ or 0.08 per $\mathrm{ppm}$, in other words, $0.03 \mu \mathrm{g} / \mathrm{m}^{3}$ of BD causes a benchmark cancer risk of $1 \times 10^{-6}[1,68]$. Because the ambient $\mathrm{BD}$ concentrations in most urban areas usually range from approximately 0.1 to $1 \mu \mathrm{g} / \mathrm{m}^{3}$, the cancer risk for the general population in cities is around $10^{-5}$ [41]. This has been demonstrated by many studies [24, 61, 69-73]. The concentrations of BD in small cities and rural areas are usually lower, as a result, the cancer risks are lower (approximately $10^{-6}$ ) $[74,75]$. On the other hand, the cancer risks at industrial sites or in areas with industrial point sources of $\mathrm{BD}$ are usually high [76]; the risks at heavily-polluted sites or those caused by occupational exposure can even reach $10^{-3}[27,53,77]$. Due to its high inhalation unit cancer risk, BD is often a major contributor to the total cancer risks caused by VOCs in industrial sites. For example, an investigation on process-specific emission characteristics of VOCs from petrochemical facilities in the Yangtze River Delta, China, found that the process unit producing BD had the largest cancer risk [78].

Because human exposure to $\mathrm{BD}$ is dominantly attributed to ETS, the cancer risks caused by residential exposure are usually greater than those caused by the ambient air. The cancer risks caused by residential exposure for U.S. nonsmokers have been estimated to be $4.2 \times 10^{-5}-5.3 \times 10^{-4}$ by using material-balance modeling [65].

$\mathrm{BD}$ is one of the environmental pollutants with the highest cancer risks. In almost all studies to investigate the cancer risks of pollutants, BD has been ranked as one of the top pollutants. In 2007, a U.S. study showed that among 17 pollutants, benzene, formaldehyde, and $\mathrm{BD}$ were the top three pollutants with the cancer risks on the order of $10^{-5}-10^{-4}$ [79]. In another study, McCarthy et al. used the EPA national ambient air quality data for the period 2003 through 2005 and found that among 65 air toxics, concentrations of benzene, carbon tetrachloride, arsenic, $\mathrm{BD}$, and acetaldehyde exceeded the $10^{-}$ ${ }^{6}$ benchmark level at most sites in the United States [80]. In an investigation conducted in Tianjin, China, benzene, $\mathrm{BD}$, and chloroform were listed as the top three pollutants among 10 monitored VOCs [81]. Du et al. compiled the data of 16 HAPs mostly from 2003 to 2013 in urban areas of China, and concluded that formaldehyde, 1,4-dichlorobenzene, benzene, and BD were the major risk contributors, which yielded the highest cancer risks $\left(\right.$ all $>10^{-5}$ ) [61]. Dhaini et al. investigated the cancer risks of air pollutants in Beirut, Lebanon, and discovered that benzene and BD were the major contributors, which accounted for $39-43 \%$ and $25-29 \%$ of the cumulative risks, respectively [71]. In Xi'an, China, formaldehyde, $\mathrm{BD}$, and 1,2-dichloroethane were found to be the top three contributors to the cancer risks [70]. In two coastal cities in Metro Vancouver, Canada, the top pollutants were determined to be carbon tetrachloride, benzene, and BD [72]. In Calgary, another Canadian city, the same three pollutants were also listed as the top contributors to the cancer risks [24].

\section{The metabolism of BD}

$\mathrm{BD}$ is an indirect carcinogen, i.e., it must be biotransformed into metabolites to exert its mutagenicity/carcinogenicity. Actually, non-carcinogenic effects of $\mathrm{BD}$ are also considered to be mediated by its metabolites [1].

It has long been known that $\mathrm{BD}$ can be metabolized to form 3,4-epoxy-1-butene (EB) by cytochrome P450 enzymes (P450s), which can be further biotransformed into 1,2,3,4-diepoxybutane (DEB) by P450s, or into 3-butene1,2-diol (BDD) by epoxide hydrolase (Fig. 1). BDD can be converted to 3,4-epoxybutane-1,2-diol (EBD) by P450s [1, 6], which was recently reported to undergo further bioactivation to form a bifunctional epoxy aldehyde [82]. DEB can also be converted to EBD by epoxide hydrolase. The three epoxides, EB, DEB, and EBD, can readily react with nucleosides and DNA to yield DNA adducts, and are genotoxic and mutagenic [7, 83-87]. In vivo, BDD and EBD are the most abundant metabolites, and DEB is the metabolite with the lowest concentrations $[6,7,88]$.

Because of the presence of two epoxy moieties in the molecule, DEB not only has stronger reactivity in comparison with EB and EBD [89-91], but also can form DNA cross-links [7, 83, 92-96] and DNA-protein crosslinks [97]. As a result, clastogenicity of DEB is very high; among 100 IARC carcinogens (Group 1, 2A, and 2B), DEB shows highest level of micronucleus (MN) induction in mice [98]. DEB is the most genotoxic and mutagenic metabolite among the three epoxides with the relative potencies of DEB >> EB > EBD [6, 7]. However, it should be noted that the relative potencies can be different when considering the stereochemistry of the metabolites. A specific EBD stereoisomer, $(2 R, 3 S)$-EBD, has been found to be at least 30-fold more mutagenic than the other three EBD stereoisomers [99]. Importantly, the mutagenic potency of $(2 R, 3 S)$-EBD is 10 -to-20-fold 


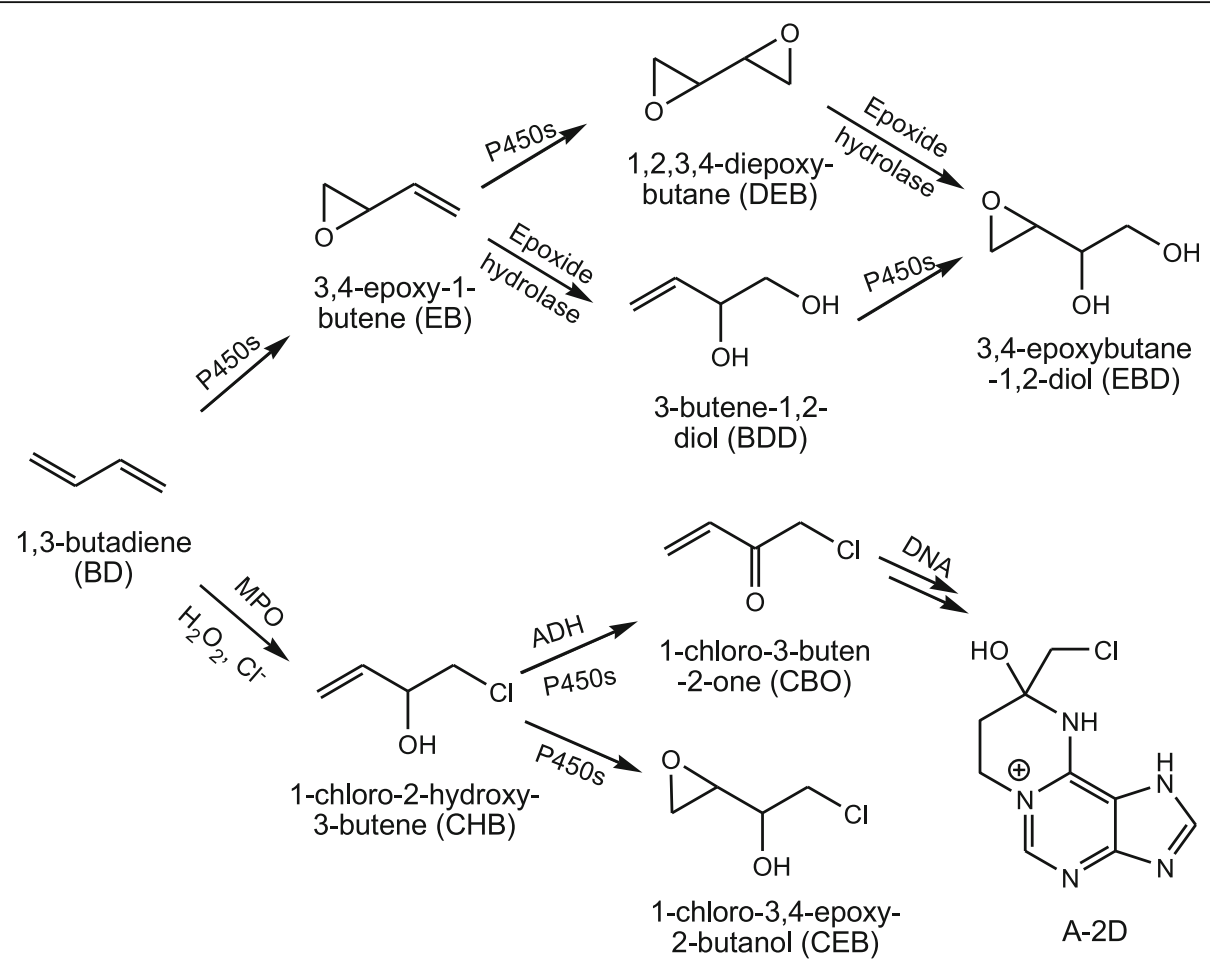

Fig. 1 The metabolic pathways of BD. The P450-mediated metabolism is an established pathway and the MPO-mediated one is a proposed pathway. (P450s, cytochrome P450 enzymes; ADH, alcohol dehydrogenase; MPO, myeloperoxidase; GSH, glutathione)

greater than EB stereoisomers and is only 5-to-10-fold less than DEB stereoisomers [99].

An alternative metabolic pathway has been proposed, in which $\mathrm{BD}$ is converted to 1-chloro-2-hydroxy-3-butene $(\mathrm{CHB})$ in the presence of hydrogen peroxide and chloride anion $(>50 \mathrm{mM})$ by myeloperoxidase (MPO), a peroxidase almost specifically present in neutrophils and monocytes [100-102]. CHB, a chlorohydrin, can be converted to 1-chloro-2-buten-2-one (CBO) and 1-chloro3,4-epoxy-2-butanol (CEB) by P450s or alcohol dehydrogenase $(\mathrm{ADH})$ [103-105]. CBO, a strong Michael acceptor, rapidly reacts with glutathione (GSH) to yield GSH conjugates [103], and can also readily react with nucleosides and DNA to form multiple DNA adducts [106-109], among which an adenine adduct, A-2D (Fig. 1 ), was detected in cells treated with low concentrations of $\mathrm{CBO}$ [109]. Importantly, $\mathrm{CHB}$ is mutagenic as determined by the Ames test, and $\mathrm{CHB}, \mathrm{CBO}$, and $\mathrm{CEB}$ are all genotoxic as assessed by the comet assay with $\mathrm{CBO}$ being much more potent than CHB, CEB, and also DEB $[105,110]$.

The alternative metabolic pathway may exist in the bone marrow and blood, which contains abundant neutrophils. Preliminary data showed that the MPOmediated metabolism of BD could occur in murine neutrophils and fresh human blood [111]. Thus, it has been proposed that this pathway may play a role in carcinogenesis of BD in humans [101, 102], because the lymphohematopoietic system, i.e., the bone marrow, is the target organ for $\mathrm{BD}$ in humans on the basis of the epidemiological studies $[1,68]$.

Although it has been established that the mutagenic and carcinogenic effects of BD are caused by its genotoxic metabolites, the specific metabolite(s) responsible for the effects are still in debate. Among the three epoxides, DEB is often considered to be the ultimate culprit responsible for $\mathrm{BD}$ mutagenicity/carcinogenicity [95, $112,113]$ due to its highly genotoxic and mutagenic potency compared to EB and EBD [6, 7, 83, 84]. On the other hand, EB and EBD have also been proposed to be the predominant cancer-initiating metabolites due to their much higher in vivo concentrations (especially EBD) compared to DEB [114], and the role of EBD has been implicated through experiments in BDD-dosed mice and rats [87].

Making the issue more complex, what metabolite(s) are responsible for $\mathrm{BD}$ mutagenicity/carcinogenicity appears to be species- and BD concentration-dependent [87]. Specifically, the culprits are considered to be DEB in mice, and EB and/or EBD in rats; or, DEB and EBD are considered responsible for the toxic effects of $\mathrm{BD}$ at low and high BD levels, respectively [87, 114]. For humans, the issue remains to be elucidated but DEB is thought to contribute little to $\mathrm{BD}$ carcinogenicity and 
EBD may cause the greatest risk $[115,116]$. Another study estimates that DEB and EBD contribute 7\% and $92 \%$ to the total genotoxic dose in humans, respectively [117]. Consistent with the observation is the finding that treosulfan, a chemotherapeutic agent that is nonenzymatically converted to DEB as its bioactive form [118], induces different histological subtypes of lymphohematopoietic neoplasms (acute myeloid leukemia) from those caused by occupational exposure to BD. Therefore, it has been speculated that monoepoxide metabolites may play a more important role than DEB in BD carcinogenesis in humans [119].

\section{Urinary biomarkers of BD}

\section{Urinary $B D$ biomarkers reported in the literature}

$\mathrm{EB}, \mathrm{DEB}, \mathrm{EBD}$, and $\mathrm{CBO}$ (Fig. 1) are reactive metabolites and can react with proteins (e.g., hemoglobin) and DNA. The products formed, i.e., hemoglobin and DNA adducts, can be used as biomarkers [120, 121]. Meanwhile, these metabolites can also undergo biotransformation via the mercapturic acid pathway to yield $\mathrm{N}$-acetyl-Lcysteine (NAC) conjugates, which are excreted in urine and can be used as biomarkers as well. BDD and CHB need to be converted to other intermediates, presumably hydroxymethyl vinyl ketone and $\mathrm{CBO}$, respectively, before biotransformation via the mercapturic acid pathway.

However, to detect hemoglobin and DNA adducts, blood and tissue samples are usually needed, which greatly restricts the application of these biomarkers in studies involving human subjects due to the difficulty in collecting the specimens. By contrast, urine is readily available and has fewer biohazard concerns. Moreover, a large proportion of absorbed BD (usually $30-60 \%$ as observed in mice, rats, and monkeys) is excreted in urine as biotransformed products [122, 123], therefore, the amounts of the biotransformed products in urine are expected to be larger than those in other biological matrices (e.g., blood and tissues). As a result, urinary BD biomarkers have been widely used, particularly in studies concerning human subjects. Thus, in this section, we will only review progress in urinary BD biomarkers.

Through the mercapturic acid pathway, EB is primarily biotransformed into two regioisomers, $N$-acetyl-S-[1-(hydroxymethyl)-2-propen-1-yl]-L-cysteine (MHBMA1) and $\mathrm{N}$-acetyl-S-(2-hydroxy-3-buten-1-yl)-L-cysteine

(MHBMA2) (Fig. 2) (it should be noted that each of the two regioisomers consists of two diastereomers), which are collectively called monohydroxybutenyl mercapturic acid (MHBMA) [2, 124, 125]. In addition, a small fraction of EB can undergo a rearrangement of double bond to yield $N$-acetyl-S-(4-hydroxy-2-buten-1-yl)-L-cysteine (configurations unspecified, presumably trans-), a trace product usually called MHBMA3 [126, 127]. The corresponding biotransformation products of BDD, EBD,
$\mathrm{DEB}$, and $\mathrm{CHB}$ are $N$-acetyl-S-(3,4-dihydroxybutyl)-Lcysteine (DHBMA), $N$-acetyl-S-(2,3,4-trihydroxybutyl)L-cysteine (THBMA), 1,4-bis ( $N$-acetyl-L-cystein- $S$-yl)butane-2,3-diol (bis-BDMA), and 1,4-bis( $N$-acetyl-Lcystein-S-yl)-2-butanone (NC1) (Fig. 2), respectively [103, 104, 113, 125, 128, 129].

DNA adducts can be released from DNA spontaneously or via the DNA repair process. The DNA adducts released are eventually excreted in urine and thus can also be used as urinary biomarkers. Although many BDderived DNA adducts have been identified [7], so far only two DNA adducts, N7-[1-(hydroxymethyl)-2-propen-1-yl]guanine (EB-GII) and 1,4-bis(gua-7-yl)-2,3butanediol (bis-N7G-BD), have been used as urinary biomarkers [130, 131].

\section{MHBMA and DHBMA}

MHBMA and DHBMA are the classic biomarkers of BD and have been used for almost 30 years [124, 132, 133]. They are the major metabolites of $\mathrm{BD}$ in urine with the sum of the amounts constituting $50-90 \%$ of the total amounts of all urinary metabolites in different species (mouse, rat, hamster, and monkey) [125]. In humans, DHBMA is the most abundant metabolite in urine and is readily detected $[113,132]$. MHBMA is more sensitive that DHBMA [133-136]. The two biomarkers, especially DHBMA, have been used in population-based studies $[44,64,136]$.

Due to the difficulty in chromatographic separation of the two regioisomers, in most studies the sum of the amounts of MHBMA1 and MHBMA2 is used as a single biomarker (i.e., MHBMA) [124, 135-138]. In some studies, the two regioisomers are separated and the concentrations of individual regioisomers are reported. The data obtained show that MHBMA2 is the dominant isomer in human urine $[64,139]$.

\section{MHBMA3}

MHBMA3 is a biomarker that is worth special attention. The metabolite was first discovered in 1995 through the reaction of EB with NAC under reflux; its structure was characterized but the configuration (trans- or cis-) was not determined. However, this product failed to be detected in urine of rats and mice administered EB [126]. It turned out to be an issue of sensitivity of the instrumental method, because in a subsequent study, Richardson et al. successfully detected the metabolite in urine of rats and mice administered ${ }^{14} \mathrm{C}$-labeled EB. Nonetheless, MHBMA3 was a trace metabolite with the amounts being only $0.5 \%$ of the administered doses or even less [127]. In 1999, the metabolite was detected in urine of mice exposed to ${ }^{14} \mathrm{C}$-labeled BD but accounted for only $0.1 \%$ of the administered doses, however, it was virtually not present in urine of rats under the same $\mathrm{BD}$ exposure 




Fig. 2 The structures of the urinary BD biomarkers reported in the literature. MHBMA1, N-acetyl-S-[1-(hydroxymethyl)-2-propen-1-yl]-L-cysteine; MHBMA2, N-acetyl-S-(2-hydroxy-3-buten-1-yl)-L-cysteine; trans- and cis-MHBMA3, trans- and cis-N-acetyl-S-(4-hydroxy-2-buten-1-yl)-L-cysteine; DHBMA, N-acetyl-S-(3,4-dihydroxybutyl)-L-cysteine; THBMA, N-acetyl-S-(2,3,4-trihydroxybutyl)-L-cysteine; bis-BDMA; 1,4-bis(N-acetyl-L-cystein-Syl)butane-2,3-diol; NC1, 1,4-bis(N-acetyl-L-cystein-S-yl)-2-butanone; NAC, N-acetyl-L-cysteine; EB-GIl, N7-[1-(hydroxymethyl)-2-propen-1-yl]guanine; bis-N7G-BD, 1,4-bis(gua-7-yl)-2,3-butanediol. MHBMA1 and MHBMA2 are collectively called monohydroxybutenyl mercapturic acid (MHBMA), and trans- and cis-MHBMA3 are similarly called MHBMA3.

[128]. It is noted that in the experiment, the amount of MHBMA was at least 120 -fold greater than that of MHBMA3 [128].

Probably due to its tiny amounts in urine of rats and mice, no studies concerning MHBMA3 have been published over the following decade. The next study involving the metabolite was published in 2012, when Alwis et al. detected MHBMA3 in human urine for the first time [139]. It is worth noting that the urine samples were collected from the general U.S. population, rather than the subpopulation with high exposure (workers occupationally exposed to $\mathrm{BD}$ ). Furthermore, it is unexpected that MHBMA3 turned out to be the most abundant metabolite in human urine among the three EB-derived metabolites (MHBMA1, MHBMA2, and MHBMA3, which were quantitated separately) with the concentrations being $36 \pm$ 34 and $6.40 \pm 10 \mathrm{ng} / \mathrm{mL}$ for smokers and non-smokers, respectively. Surprisingly, MHBMA3 had a very high frequency of detection (99\%). By sharp contrast, MHBMA1 failed to be detected in a vast majority of samples (either smokers or non-smokers) and MHBMA2 was detected only in urine of smokers but its concentrations were very low [the mean concentration was $1.80 \pm 2.10 \mathrm{ng} / \mathrm{mL}$ with the limit of detection (LOD) being $0.70 \mathrm{ng} / \mathrm{mL}$ ] [139]. The finding was confirmed by a recently published study with 5,897 participants, in which the frequency of detection of MHBMA1 and MHBMA2 in urine samples was only $0.7 \%$ and $9.8 \%$, respectively [64]. This is opposite to the observation in animal experiments, in which MHBMA1 and MHBMA2 were overwhelmingly dominant metabolites formed, and MHBMA3 could hardly be detected [128].

Following the report of Alwis et al., more than 10 studies on the general population using MHBMA3 as the BD biomarker have been published, with most studies being conducted in the U.S. populations $[44,63,64$, 140-153]. These studies performed in the general U.S. populations showed similar results to those reported by Alwis et al. [139]. However, the results obtained in the populations in other countries and regions are different. Chiang et al. reported that the mean MHBMA3 concentrations in 55 Taiwanese smokers and 55 non-smokers were $129.2 \pm 99.2$ and $52.3 \pm 36.8 \mathrm{ng} / \mathrm{mL}$, respectively [140], which were considerably higher than that reported by Alwis et al., in particular, the concentrations in non- 
smokers. A recently published study on the general population in Wuhan, China, reported a surprisingly low frequency of detection at only 9.4\% [152]. Similarly, another study performed in China even failed to detect MHBMA3 in 100 urine samples from children aged 6-12 years [153]. A possible explanation for the surprising observations reported in the two studies is that the authors used cisMHBMA3 as the reference standard and the LOD in the latter study was somewhat high $(3.13 \mathrm{ng} / \mathrm{mL})[152,153]$, although in the studies of Alwis et al. [139] and other authors [44, 63, 64, 140-148, 151], the configuration of the MHBMA3 standard was not specified.

MHBMA3 is a sensitive BD biomarker. It can clearly distinguish non-smokers from smokers. In fact, all population-based studies consistently show that there are statistically significant differences in the MHBMA3 concentrations between smokers and non-smokers [63, 64, 139-142, 149, 151]. Quitting smoking can be reflected in the change in the MHBMA3 level; in a study on over 1,100 adult exclusive daily cigarette smokers, a dramatic reduction in the MHBMA3 level was observed among those quitted tobacco use entirely [147]. The biomarker can also indicate exposure to ETS; in an investigation on exposure of non-smokers to VOCs from secondhand smoke, St. Helen et al. observed that the MHBMA3 concentrations exhibited the greatest increase (2.1-fold) from 0 to $8 \mathrm{~h}$ postexposure among $9 \mathrm{VOC}$ biomarkers [154]. In addition, MHBMA3 can even discriminate between duel cigarette/e-cigarette users and exclusive cigarette smokers [141]. Furthermore, the biomarker can distinguish among light, average, and heavy smokers. In Wave 1 of the Population Assessment of Tobacco and Health Study, the biomarker data of more than 2,700 U.S. adult daily cigarette smokers were analyzed and it was observed that the concentrations of biomarkers, including MHBMA3, consistently increased with cigarettes smoked per day (CPD) [141]. In the 2011-2016 U.S. National Health and Nutrition Examination Survey, by examining the urinary BD biomarkers, including MHBMA1, MHBMA2, MHBMA3, and DHBMA, in 5,897 participants, Nieto et al. observed clear dose-response relationships between the MHBMA3 or DHBMA concentrations and CPD [64]. Specifically, compared to non-smokers, smoking 1-10, 11-20, and > 20 CPD was significantly associated with $475 \%$, $849 \%$, and 1,143\% higher MHBMA3 levels, respectively (all $p<$ 0.0001). However, the corresponding increases for DHBMA were only $32.8 \%, 44.2 \%$, and $102 \%$, respectively [64]. In addition, another study showed that the increase in number of days that the tobacco products were used during the last five days was associated with increased levels of MHBMA3 $(p<0.01)$ but not DHBMA [149].

Besides smokers and non-smokers, significant differences in the MHBMA3 levels have also been observed among different subpopulations, including those with different gender, ethnic/racial group, and age, although the results are not always consistent. For example, it has been discovered that the MHBMA3 levels in female smokers were significantly high than those in male smokers [64, 142, 149]. When comparing differences among different ethnic/racial groups, the MHBMA3 levels in non-Hispanic white smokers were observed to be higher than those in nonHispanic black ones [149]. Another study also found that the MHBMA3 levels in non-Hispanic white were significantly higher than those in non-Hispanic black and Hispanic [142]. However, the differences failed to be observed in a recently published study [64].

The differences among subpopulations with different ages were consistently observed by three groups of authors. Jain reported that there was a statistically significant positive association between the MHBMA3 level and age [149], and specifically, children aged 6-11 years old had significantly higher MHBMA3 level compared to non-smoker adults aged $\geq 20$ years [150]. De Jesus et al. found that after controlling for tobacco use and other cofactors and using participants' age of 25-34 years as the reference, young adults (18-24 years) had significantly lower MHBMA3 levels, but older adults $(\geq$ 55 years) had significantly higher levels (all $p \leq 0.0001$ ) [142]. Similar results were also obtained in a recent study reported by Nieto et al., although in this study, age was categorized into somewhat different ranges from the preceding study. In this study, Nieto et al. reported that the MHBMA3 concentrations in older adults (aged 4059 and $\geq 60$ years) were significantly higher compared to those in younger adults (aged 20-39 years) [64]. Among all participants $(n=5,897)$ and the participants who did not use tobacco products $(n=5,171)$, with the exception of adolescents (aged 12-19 years), all age groups, including children (aged 3-5 and 6-11 years), had higher MHBMA3 levels compared with young adults (aged 2039 years) [64], which is consistent with the observation reported by Jain [150].

A major issue concerning MHBMA3 is that its configuration is not specified in all studies except for two recent ones [152, 153]. This compound has two configurations or two stereoisomers, i.e., trans- and cisMHBMA3 (Fig. 2), which should be well separated chromatographically. Unlike MHBMA, which is the mixture of MHBMA1 and MHBMA2 and is usually used as a single biomarker in most studies, the researchers in MHBMA3-related studies did not describe that this compound was a mixture of two stereoisomers. Moreover, the MHBMA3 standards available commercially are either trans- or cis-isomer. Therefore, MHBMA3 detected in human urine should be one of the two stereoisomers rather than the mixture of the two stereoisomers. It has not been clear whether the 
difference in the frequency of detection of MHBMA3 between the studies of Qian et al. or Kuang et al. [152, 153] and those reported by other authors [44, 63, 64, $139-148,151]$ is caused by the configuration of the biomarker.

\section{THBMA}

THBMA was tentatively identified first in urine of mice exposed to BD [155] and was confirmed later by using animals exposed to ${ }^{14} \mathrm{C}$-labeled $\mathrm{BD}$ [128]. Interestingly, the metabolite was not detected in urine of rats and mice administered ${ }^{14} \mathrm{C}$-labled EB [127]. In 2000, van Sittert et al. tried to detect THBMA in human urine but the attempt was unsuccessful due to interferences from the sample matrix [124]. Until 2011, the Tretyakova laboratory was able to develop an LC-MS/MS method to detect the metabolite in human urine, whose concentrations in smokers and non-smokers were reported to be 21.6 and $13.7 \mathrm{ng} / \mathrm{mg}$ creatinine with the difference being statistically significant $(p<0.01)$, respectively. Furthermore, the THBMA concentrations in urine declined 25$50 \%$ following smoking cessation [129]. The biomarker was also detected in urine of workers occupationally exposed to BD with the mean concentration being $157 \mathrm{ng} /$ mg creatinine [113]. A subsequent study on workers in Czech Republic observed statistically significant differences not only between exposed workers and the control, but also between the male control and the female control. The MHBMA concentrations in the male control were significantly higher than those in the female control ( $57.1 \pm 33.5$ vs. $24.2 \pm 16.6 \mathrm{ng} / \mathrm{mL}$, respectively) even though both control groups were exposed to the same ambient BD levels $\left(7 \pm 5 \mu \mathrm{g} / \mathrm{m}^{3}\right)$ [135].

\section{bis-BDMA}

Bis-BDMA was first synthesized in 2014 by the Tretyakova group and was used as a biomarker [113]. In rat urine following exposure to $200 \mathrm{ppm}\left(442 \mathrm{mg} / \mathrm{m}^{3}\right) \mathrm{BD}$ for two weeks, the mean bis-BDMA concentration was $4.8 \pm 2.9 \mu \mathrm{g} / \mathrm{mL}$, which was $16-$, 44-, and 31-fold lower than those of MHBMA, DHBMA, and THBMA, respectively. However, this biomarker was not detected in urine of smokers and workers occupationally exposed to $\mathrm{BD}$ [113]. In urine of mice exposed to $590 \mathrm{ppm}(1,300 \mathrm{mg} /$ $\mathrm{m}^{3}$ ) BD for two weeks, the bis-BDMA concentration was $8.09 \pm 6.3 \mu \mathrm{g} / \mathrm{mL}[131]$.

\section{NC1}

$\mathrm{NC} 1$ is the urinary biomarker of $\mathrm{CHB}$, the potential $\mathrm{BD}$ metabolite formed via the alternative MPO pathway. It was first synthesized in 2017 [111, 156] and subsequently was detected in urine of CHB-administered rats and mice [104]. Whether the biomarker can be detected in urine of animals and humans exposed to BD has not been reported.

\section{EB-GII}

EB reacts with the guanine residues in DNA at the N7position to form two products, N7-(2-hydroxy-3-buten1-yl) guanine (EB-GI) and EB-GII [157]. The two adducts have been detected in EB-treated cells in culture, and in tissues of rats and mice exposed to BD [157], and EB-GII has been found in human blood leukocyte DNA of smokers but below the LOD [158]. In 2017, the Tretyakova laboratory developed a highly sensitive LC-MS/ MS method and was able to detect EB-GII in urine of smokers and occupationally-exposed workers [130]. The biomarker was successfully used in studies concerning humans and animals [159-161].

\section{bis-N7G-BD}

Bis-N7G-BD was first synthesized through the reaction of DEB with guanosine [92]. The adduct can be detected in tissues of rats and mice exposed to BD [95]. Use of bis-N7G-BD as a urinary biomarker was reported just before the review is published [131]. In the study, very low concentrations of bis-N7G-BD ( $570 \mathrm{pg} / \mathrm{mg}$ creatinine) were detected in urine of mice exposed to $590 \mathrm{ppm}$ $\left(1,300 \mathrm{mg} / \mathrm{m}^{3}\right) \mathrm{BD}$ for two weeks [131].

\section{Suitability of the urinary BD biomarkers for studies on the general population}

Urinary biomarkers are particularly useful in large epidemiological studies because urine is much more easily available and has lower biohazard risks compared to blood. However, it should be noted that urinary biomarkers reflect recent exposures and are susceptible to variations [134]. Because several urinary BD biomarkers have been developed, a comparison of their performance can help researchers make a wise selection, especially for studies on the general population.

The urinary BD biomarkers reported can be divided into two categories: exposure biomarkers and exposure/ effect biomarkers. The former includes all NAC conjugates and is surrogate biomarkers, because they only reflect the doses of internal exposure to $\mathrm{BD}$ or a specific metabolite (e.g., DEB). On the other hand, the latter, which includes EB-GII and bis-N7G-BD, is mechanistically relevant and cancer-related biomarkers, because the formation of DNA adducts is considered to be the initial molecular event in carcinogenesis.

First and foremost, selection of biomarkers is certainly dependent on the purpose of research. However, in practical applications, the selection primarily depends what subjects are used in research. Urine of laboratory animals exposed to BD usually contains high concentrations of metabolites, thus all BD biomarkers can virtually 
be used. Conversely, urine of human subjects in the general population is expected to contain very low concentrations of biomarkers, as a result, selection of biomarkers is quite restricted. Because urinary BD biomarkers are most useful in biomonitoring of human subjects and for laboratory animals, hemoglobin and DNA adducts can be freely selected as biomarkers, we will thus focus on the issue what biomarkers are suitable for studies on the general population.

Among the urinary BD biomarkers, MHBMA and bisBDMA can easily be excluded due to either very low frequency of detection [64] or inability to be detected even in urine of occupationally-exposed workers [113]. Among other biomarkers, DHBMA, THBMA, and EBGII have natural background that may be caused by endogenous sources, thus restricting their sensitivity [113, $124,130,133]$. Specifically, DHBMA fails to reflect the changes in the external exposure doses in some studies $[137,162]$; in particular, a study found that the DHBMA levels did not change after cessation of smoking, whereas the levels of MHBMA and the biomarkers of other VOCs rapidly decreased [137]. The difference in the THBMA concentrations between smokers and nonsmokers is small (the data of smokers is only $58 \%$ higher than that of non-smokers), although it is statistically significant $(p<0.01)$ [129]. EB-GII is even worse; its concentrations in urine of smokers had no statistically significant difference from those in non-smokers [130]. However, the levels of these biomarkers exhibited significant differences between occupationally exposed workers and the controls, suggesting that they may be suitable for human subjects with high BD exposure.

Among these biomarkers, MHBMA3 stands out from the rest. Many studies already demonstrate its excellent suitability for biomonitoring exposure of the general populations to ambient $\mathrm{BD}$ [44, 63, 64, 140-153]. It is highly responsive to the exposure dose [64] and is well capable of reflecting exposure to ETS [154]. Compared with DHBMA, MHBMA3 exhibits stronger correlation with the serum level of cotinine, the well-known biomarker for smoking [139]. In addition, the MHBMA3 levels also show significant differences among a variety of subpopulations [64, 142, 149]. Clearly, MHBMA3 is the best urinary biomarker for biomonitoring BD exposure in the general population.

\section{Genotoxicity of BD in humans}

Genotoxicity of BD in humans, as assessed in many molecular epidemiology studies, has been thoroughly reviewed in 2010 by Albertini et al. [7]. After that, only five studies, which were performed by two groups of Chinese researchers, have been published. Therefore, we will only provide a brief update on the issue.
The Xia group in the School of Public Health of Fudan University used the cytokinesis-block micronucleus (CBMN) assay to examine chromosomal damage in peripheral blood lymphocytes (PBL) of 166 workers in a polybutadiene latex chemical industrial plant in Ningbo, China [163]. These workers were exposed to extremely high levels of BD with the range varying from 0.05 to $1,985.99$ $\mathrm{mg} / \mathrm{m}^{3}$ (the median was $4.48 \mathrm{mg} / \mathrm{m}^{3}$ ). The mean MN frequency of the workers was significantly higher than that of the unexposed control $(0.339 \%$ vs. $0.148 \%, p<0.01)$, and the polymorphisms of several genes involved in bioactivation and detoxification of BD were observed to influence the MN frequency [163]. In another study, the Xia group used sister-chromatid exchange (SCE) and CBMN assays to investigate chromosomal damage in PBL of 44 BD-exposed workers in a rubber factory of Shandong, China [164]. These workers were exposed to much lower levels of BD $\left(0.06-12.41 \mathrm{mg} / \mathrm{m}^{3}\right.$ with the median being $1.48 \mathrm{mg} / \mathrm{m}^{3}$ ) compared with those in Ningbo, China. It was found that the mean $\mathrm{MN}$ frequency in the workers was significantly higher than that in the control without occupational exposure to $\mathrm{BD}(0.439 \%$ vs. $0.296 \%, p<$ 0.01 ), but the SCE frequency did not exhibit statistically significant difference between the exposed workers and the control. In addition, it was also observed that the polymorphisms of three glutathione $S$-transferase genes affected the MN frequency [164].

The other group of Chinese researchers, the Cao and Ao group in the Department of Hygiene Toxicology of the Third Military Medical University, Chongqing, China, conducted a 1:1 matched pair study in a population of workers in a large petrochemical facility in Nanjing, China [165-167]. The workers were exposed to significantly higher levels of $\mathrm{BD}$ than did the control (5.02 vs. $1.86 \mathrm{mg} / \mathrm{m}^{3}, p<0.01$ ), and exhibited elevated frequency of $\mathrm{MN}$ and nucleoplasmic bridge (NPB) (both $p<0.01)$ but lower nuclear division index $(p<0.01)$ in comparison to the control [165]. The polymorphisms of some metabolism- and DNA repair-related genes, and a folate metabolism-related gene were observed to affect the NPB and nuclear bud frequency [165-167].

Additionally, it is noted that a study performed in Italy observed a statistically significant increase in the MN frequency of exfoliated buccal cells in petroleum refinery workers and also residents living in areas close to the petroleum refinery industry [168]. However, the cohort was small $(n=50)$ and the BD concentrations were not measured.

In summary, these studies indicate that BD at levels of occupational exposure is genotoxic to humans and can cause chromosome damage as assessed by the CBMN assay. However, a vast majority of studies published before 2010 have failed to observe genotoxicity of BD in humans [7]. It seems to be an issue of selection of assays 
and endpoints, because the previous studies examined the mutations of the hypoxanthine-guanine phosphoribosyltransferase (HPRT) gene, and induction of chromosome aberrations and SCE [7]. Thus, the CBMN assay appears to be the technique of choice to detect genotoxicity of BD in humans. Chromosome damage detected with the assay may be used as an effect biomarker to assess cancer risk induced by BD [169].

\section{Associations between BD exposure and diseases}

Exposure to $\mathrm{BD}$ has been associated with a variety of diseases. First and foremost, as a human carcinogen, occupational exposure to BD has been causally associated with lymphohematopoietic cancers, especially leukemia $[1,2,4]$. With regard to specific forms of leukemia, the epidemiological studies of a cohort of synthetic rubber industry workers at six North American plants support an association between BD exposure and lymphoid leukemia, but not myeloid leukemia, non-Hodgkin's lymphoma, and multiple myeloma [170-173].

$\mathrm{BD}$ exposure has also been associated with diseases other than lymphohematopoietic cancers, including cardiovascular disease (CVD), reproductive effects, childhood leukemia, etc. It is worth noting that children may be one of the subpopulations with greater susceptibility to the toxic effects of $\mathrm{BD}$ than the general population; in fact, most epidemiological studies over the last decade have been conducted on children. Thus, the studies of the adverse effects of BD on children's health will be discussed in a separate section.

\section{CVD}

The association between BD exposure and CVD was first noticed in 1990. Interestingly, the association was observed only in a specific subpopulation, i.e., black male. In a study to investigate the mortality among workers at a BD facility, Divine reported a significantly elevated standardized mortality ratio (SMR) in non-white males for all causes of death, including arteriosclerotic heart disease [174]. The data from another study to investigate 12,110 male workers in eight styrene-BD polymer manufacturing plants indicated a significant excess SMR for arteriosclerotic heart disease $(\mathrm{SMR}=1.48)$ in black workers than in the general population [175]. In 1996, Divine and Hartman reported updated data and similarly found that, in the cohort of 2,795 male workers at a BD facility, the non-white workers showed a statistically significant elevated SMR for all causes of death, including arteriosclerotic heart disease $(S M R=1.42)$ [176]. In a cross-sectional study, Shin et al. observed that BDrelated VOCs decreased diastolic blood pressure but increased heart rate and brachial artery diameter, suggesting that $\mathrm{BD}$ and other VOCs may have rapid impacts on the human cardiovascular system [177]. In this study, more than half of 63 participants were black people $(n=$ $35,55.6 \%)$ [177].

The observation that BD exposure was associated with CVD in black male was echoed by a newly published study, in which the urinary levels of DHBMA were observed to exhibit strong associations with the urinary levels of norepinephrine and normetanephrine (two CVD risk markers) in black participants of a cohort of 346 non-smokers [148]. The result suggested that exposure to $\mathrm{BD}$ was associated with endothelial dysfunction and may contribute to elevated risk of hypertension in people with increased sympathetic tone, particularly in black individuals [148].

Lin et al. recently reported a positive correlation between the urinary DHBMA levels and the CVD risk factors, including carotid intima-media thickness, endothelial microparticles, and platelet microparticles [178]. However, the study was conducted in young Taiwanese.

The association between BD exposure and CVD is supported by animal experiments [179, 180]. Crotonaldehyde, a minor $\mathrm{BD}$ metabolite, might play a role in the etiology [181].

\section{Reproductive effects}

BD has been considered to have reproductive and developmental effects [182]. However, so far the effects have been observed dominantly in rodents; these effects include reduced fetal weight, fetal death, ovarian atrophy, and testicular atrophy, and the most sensitive endpoints are ovarian atrophy in female mice and testicular atrophy in male mice $[1,183]$. DEB may be the critical metabolite to induce the reproductive effects $[1,182]$; Dong et al. reported that DEB caused the proliferation inhibition and marked cell cycle arrest at the G2 phase but not apoptosis in mouse spermatocyte-derived GC-2 cells [86].

The studies of the reproductive effects of BD on humans have been extremely scarce. The data from an earlier study on Czech female workers exposed to BD showed no difference in pregnancy outcomes (e.g., miscarriage, still birth, ectopic pregnancies) between exposed subjects and controls. However, the numbers of the subjects and controls in this study are small ( $n=23$ and 26, respectively) [184]. In a recently published study conducted in Portland, Oregon, U.S., Willis and Hystad used vital statistics records from 2000 to 2014 ( $n=279,051$ births) to assess prenatal exposure to 19 air pollutants. They observed associations in fully adjusted models comparing the highest to lowest quintiles of exposure for certain pollutants, including the associations between $\mathrm{BD}$ and term birth weight $[-16.86 \mathrm{~g}$; 95\% confidence interval $(\mathrm{CI})=-29.66$ -4.06; $p<0.05$ ], and between $\mathrm{BD}$ and small for gestational age [odds ratio $(\mathrm{OR})=1.18 ; 95 \% \mathrm{CI}=1.07-1.30 ; p<0.05$ ] [185]. Another recent study indicated that there might be a potential association between $\mathrm{BD}$ exposure and male 
infertility. Poli et al. reported that the urinary DHBMA levels were negatively correlated with sperm count and sperm abnormal forms, and oxidative stress on the male reproductive tract may play an important role [186].

\section{Adverse effects on pulmonary functions}

Occupational exposure to high concentrations of $\mathrm{BD}$ may have adverse effects on pulmonary functions, including vital capacity, forced vital capacity, forced expiratory volume in the first second, and peak expiratory flow. An investigation on workers in a petrochemical plant in Iran found that compared to the control, the workers had considerably higher prevalence rates of cough, phlegm, wheezing, shortness of breath, chest tightness, and episodes of chest illness associated with cold. Furthermore, their pulmonary functions were also lower in comparison with the control and the differences were statistically significant $(p<0.05)$ [187]. However, it should be noted that the workers were exposed to high $\mathrm{BD}$ concentrations (the average concentration reached $560.82 \mu \mathrm{g} / \mathrm{m}^{3}$ ), although the BD levels are still below the threshold recommended by the American Conference of Governmental Industrial Hygienists [187].

\section{Associations between BD exposure and diseases in a specific subpopulation - children}

Most epidemiological studies over the last decade to investigate the associations between $\mathrm{BD}$ exposure and diseases were conducted in children. Exposure to BD has been reported to show associations with several childhood diseases, including childhood leukemia, brain tumors, autism, asthma, etc. The studies are discussed below.

\section{Childhood leukemia}

Childhood leukemia accounts for approximately $30 \%$ of all childhood cancers in the United States, and a significant increase in the incidence has been observed in Europe and in other developed countries over the past 30 years [119]. In the meantime, the etiology of childhood leukemia remains poorly understood and few established risk factors have been identified. Over the last 20 years, there has been increasing focus on environmental pollutants, especially, the traffic-related pollutants [188-192]. As a traffic-related air pollutant and a known human carcinogen that has causally been associated with leukemia, BD has naturally received much attention in the investigations for the etiology of childhood leukemia.

The association between childhood cancers, including childhood leukemia, and exposure to a variety of air pollutants $\left(\mathrm{CO}, \mathrm{NO}_{\mathrm{x}}, \mathrm{VOCs}\right.$, dioxins, etc.) was first reported by Knox in two successional studies, in which elevated risks of childhood cancers were observed among children whose residence was near a "hot spot" of benzene or BD emissions [193, 194]. Although some increased risks could be attributable to mutual confounding, BD was found to be a powerful independent predictor [194]. For the first time, BD was identified as a specific hazard for childhood cancers, although in these studies, childhood leukemia was not singled out [193].

The finding was reinforced by subsequent studies. In an ecologic study in Texas, U.S., Whitworth et al. investigated 977 cases of childhood lymphohematopoietic cancer diagnosed from 1995-2004. The researchers examined whether the census tracts with the highest estimated levels of benzene and BD had higher incidence rates of childhood lymphohematopoietic cancer compared with the census tracts with the lowest estimated levels. Indeed, among the census tracts with the highest BD levels, they observed significantly higher rates of all leukemia [rate ratio $(\mathrm{RR})=1.40 ; 95 \% \mathrm{CI}=1.07-1.81$ ], and elevated rates of the two most common types of childhood leukemia, acute myeloid leukemia (AML) (RR $=1.68 ; 95 \% \mathrm{CI}=0.84-3.35)$ and acute lymphocytic leukemia $(\mathrm{ALL})(\mathrm{RR}=1.32 ; 95 \% \mathrm{CI}=0.98-1.77)$, but the data for AML and ALL were not statistically significant [195]. The same laboratory further investigated whether in utero and early life exposure to BD and other pollutants was associated with childhood leukemia, and indeed observed positive associations between exposure to $\mathrm{BD}$ and childhood leukemia (under the age of 5) in either single or co-pollutant models [196]. In another investigation conducted in California, U.S., Heck et al. found that in infancy, AML was positively associated with exposure to $\mathrm{BD}(\mathrm{OR}=2.35 ; 95 \% \mathrm{CI}=1.02-5.39), o$-xylene $(\mathrm{OR}=$ $1.88 ; 95 \% \mathrm{CI}=1.02-3.45)$, and toluene $(\mathrm{OR}=2.02 ; 95 \%$ $\mathrm{CI}=1.03-3.94)[197]$.

\section{Childhood brain tumors}

The association between exposure to BD and childhood brain tumors has also been reported. Danysh et al. conducted a population-based study in Texas, U.S., and observed that the census tracts with medium and mediumhigh BD concentrations had higher astrocytoma incidence rates $(\mathrm{RR}=1.46 ; 95 \% \mathrm{CI}=1.05-2.01$ and $\mathrm{RR}=$ $1.69 ; 95 \% \mathrm{CI}=1.22-2.33$, respectively) compared with low concentrations. Increased concentrations of $\mathrm{BD}$ and benzene were observed to be strongly associated with increased primitive neuroectodermal tumor (PNET) incidence rates, but the associations were not statistically significant [198]. In a subsequent study, the group evaluated the influence of residential mobility on the exposure assignment and concluded that residential mobility of children did not significantly impact the exposure assignment of BD [199]. In another study in California, U.S., von Ehrenstein et al. found that central nervous system PNETs were positively associated with interquartile range (IQR) increases in prenatal exposure to acetaldehyde $(\mathrm{OR}=2.30 ; 95 \% \mathrm{CI}=1.44-3.67), \mathrm{BD}(\mathrm{OR}=2.23$; 
95\% CI $=1.28-3.88)$, benzene, and toluene; and also with IQR increases in exposure during the first year of life to $o$-dichlorobenzene $(\mathrm{OR}=3.27 ; 95 \% \mathrm{CI}=1.17-9.14), \mathrm{BD}$ $(\mathrm{OR}=3.15 ; 95 \% \mathrm{CI}=1.57-6.32)$, and benzene. The authors concluded that in utero and infancy exposures to air toxics generated by industrial and road traffic sources may increase the risk of PNETs and medulloblastoma, with limited support for increased risks for astrocytoma in children up to age 6 [200].

\section{Other childhood tumors}

Besides childhood leukemia and brain tumors, BD exposure has also been found to be potentially associated with other childhood cancers. Heck et al. examined ambient exposure to 27 air toxics in the perinatal period in relation to retinoblastoma development with the disease diagnosed during 1990-2007 in California, U.S. They observed that retinoblastoma risk increased with pregnancy exposure to benzene $(\mathrm{OR}=1.67 ; 95 \% \mathrm{CI}=1.06-2.64)$ and other six toxics that primarily arise from gasoline and diesel combustion and are highly correlated, including $\mathrm{BD}(\mathrm{OR}=1.59 ; 95 \% \mathrm{CI}=1.08-2.35)$ [201]. Prenatal exposure to air toxics, including $\mathrm{BD}$, was also observed to be positively associated with malignant germ cell tumors (GCTs) in young children [202]. In a case-control study, Hall et al. identified 243 GCT cases, which were matched by birth year to cancer-free population controls ( $n=147,100)$ from 1984 to 2013 in California, U.S. They observed that prenatal exposure to traffic-related air toxics during the second trimester increased GCT risk, particularly $\mathrm{BD}(\mathrm{OR}=1.51 ; 95 \% \mathrm{CI}=1.01-2.26)$ and $\mathrm{m}-\mathrm{l}$ $p$-xylene $(\mathrm{OR}=1.56 ; 95 \% \mathrm{CI}=1.10-2.21)$. A further analysis by subtype indicated elevated ORs for yolk sac tumors but no teratomas [202].

\section{Childhood autism}

The etiology of autism is heterogeneous and little is known about its nongenetic causes, but environmental factors have been suggested as major contributors. It has been reported that in utero $\mathrm{BD}$ exposure is associated with childhood autism [203]. In a population study, von Ehrenstein et al. identified 768 cases of autism from 148,722 children in Los Angeles County, California, U.S., during 1998-2009. They found that autism risks increased per interquartile range increase in average concentrations during pregnancy of several correlated toxics mostly loading on 1 factor, including BD (OR = 1.59; $95 \% \mathrm{CI}=1.18-2.15), m$ - $/ p$-xylene $(\mathrm{OR}=1.51 ; 95 \% \mathrm{CI}=$ 1.26-1.82), and other pollutants, adjusting for maternal age, ethnicity/race nativity, education, insurance type, parity, child sex, and birth year [203].

\section{Childhood asthma}

In a recently published article, Kuang et al. compared the differences in several biomarker levels between asthmatic and healthy children. DHBMA was used as the biomarker of $\mathrm{BD}$. The results indicated that the urinary levels of DHBMA and biomarkers of other pollutants were significantly associated with asthma (for DHBMA, $\mathrm{OR}=2.76 ; 95 \% \mathrm{CI}=1.73-4.43)$. Oxidative stress may play an important role, because these biomarkers exhibited strong correlations with 8-hydroxy-2'-deoxyguanosine levels, which were significantly higher in asthmatic children than those in healthy children [204].

\section{The role of $\mathrm{BD}$ in smoking-associated diseases}

Tobacco smoke contains over 6,000 compounds, of which more than 70 compounds have been classified as human carcinogens [205-207]. BD is one of the carcinogens with the largest amounts in mainstream smoke; its typical yield is $52 \mu \mathrm{g} /$ cigarette, which is more than 400 fold higher than 4-(methylnitrosamino)-1-(3-pyridyl)-1butanone (NNK), a strong tobacco-specific carcinogen [208]. In terms of cancer risk, BD has been ranked as the most carcinogenic compound in cigarette smoke among 40 carcinogens with cancer potency factors being available [209].

Tobacco smoking has been associated with an array of diseases, including many types of cancers (e.g., lung cancer, liver cancer, bladder cancer, and leukemia), diabetes mellitus, CVD, asthma, etc. [210]. In spite of the ranking of $\mathrm{BD}$ as the top carcinogen in cigarette smoke, the contribution of $\mathrm{BD}$ in tobacco smoking-associated diseases, in particular, cancers, has not been elucidated.

$\mathrm{BD}$ is listed as a likely but minor causative agent for cigarette smoke-related lung and larynx cancers, mostly based on its tumorigenesis in mice [205, 208, 211]. However, the latest epidemiological study on more than 20,000 workers employed at eight North American synthetic rubber polymer plants from 1943 through 2009, which is the largest cohort for occupational exposure to $\mathrm{BD}$, found that there was no causal association between BD exposure and lung cancer [212]. This study and the authors' earlier investigations indeed observed elevated rates of lung cancer among female workers, however, the authors thought that it may be caused by other factors rather than exposure to $\mathrm{BD}$ due to the lack of a positive exposure-response trend [172, 213-215]. The observation also obtains support from other independent studies, including an investigation on the relationships between several carcinogens in cigarette smoke and lung cancer in a Chinese cohort [216], an ecological study at the country level conducted in the United States [217], and an investigation on cancer incidence in a petrochemical industry area in Sweden [218]. Moreover, in a U.S. study to compare the BD metabolism in smokers in 
three ethnic/racial groups (Native Hawaiians, whites, and Japanese Americans), Park et al. found that the MHBMA levels in Native Hawaiian smokers were significantly lower compared to those in white smokers, suggesting that Native Hawaiian smokers had lower BD uptake rates or metabolized $\mathrm{BD}$ to $\mathrm{EB}$ and then MHBMA less efficiently than whites [219]. However, it has been established that for the same lifetime smoking exposure, Native Hawaiian smokers have a significantly greater risk of lung cancer than do whites [220]. Thus, the finding of Park et al. actually provides indirect support for the epidemiological observation that BD exposure has no causal association with lung cancer. Collectively, the studies suggest that BD is not a human lung carcinogen and thus is not expected to contribute to smoking-associated lung cancer.

In spite of the fact that $\mathrm{BD}$ is listed as a minor contributing agent for larynx cancer [205], in fact, the studies concerning BD exposure and larynx cancer have been very scarce. A few studies to investigate the mortality in workers from the styrene-BD rubber industry and the $\mathrm{BD}$ production industry found that certain subgroups of workers had more than expected deaths from larynx cancer $[175,176,215]$. However, the results were all based on small numbers and thus were statistically imprecise. Moreover, the excess in larynx cancer was not clearly associated with any process group, suggesting that the increases were not due to BD exposure [215]. It should be noted that a positive association has indeed been observed between occupational exposures in the rubber-manufacturing industry and larynx cancer [4]. However, the observation is unable to relate the development of larynx cancer to exposure to specific chemicals because the rubber-manufacturing industry uses a wide variety of substances. In addition, a review of literature on the contribution of various types of occupational exposure to rare cancers does not list $\mathrm{BD}$ as a possible contributor to larynx cancer [221].

Because cigarette smoke is a known risk factor for urothelial carcinoma, a recent case-control study investigated the relationships among smoking, urinary levels of several VOC biomarkers, and urothelial carcinoma risk. However, no association between the levels of MHBMA3 or DHBMA and the risk of urothelial carcinoma has been discovered [144].

Taken together, it appears that BD may not contribute to pathogenesis of cigarette smoking-associated cancers of lung and larynx. Because BD has been associated with leukemia and some types of childhood tumors, and noncarcinogenic effects such as CVD and asthma, it is likely that $\mathrm{BD}$ is involved in these diseases caused by smoking. However, to our knowledge, so far no studies to investigate the associations have been published.

\section{Discussion and perspective}

The studies of $\mathrm{BD}$ over the last decade have brought some important developments, among which the adverse effects on children's health are probably the most profound issue. However, more carefully-designed studies are needed to provide further evidence for these findings.

In epidemiological studies, it is a critical issue to determine human exposure to BD. Currently, most epidemiological studies estimated human exposure to BD based on its concentrations in the ambient air. However, the approach can cause great uncertainties for studies conducted in the general population. As pointed out by Fujita et al., estimates of population exposure to air pollutants extrapolated from ambient measurements at ambient fixed site monitors are prone to uncertainty [48]. Multiple studies have indicated that microenvironments, especially those at home, are the main determinant of human exposure and the BD concentrations in microenvironments are often unrelated to those in the ambient air. Moreover, several population studies has consistently demonstrated that with regard to human exposure to $\mathrm{BD}$, ETS is the primary source in the general population. Therefore, for epidemiological studies on the general population, a reliable estimate of human exposure to $\mathrm{BD}$ is desirable. Currently, the best approach can be using the urinary levels of BD biomarkers (preferably MHBMA3) as the metric for assessing human exposure, although it should be kept in mind that the urinary biomarkers reflect only recent exposures.

The finding that $\mathrm{BD}$ has natural sources from trees and soil bacteria is intriguing. However, so far only two tree species and a strain of soil bacterium have been reported to release BD. Thus, it is worth further exploration whether other species of plants and bacteria can also generate $\mathrm{BD}$. If the quantities generated by plants are large enough, it may have an impact on human exposure to $\mathrm{BD}$ and it is also likely that $\mathrm{BD}$ can play a role in atmosphere chemistry.

Because BD must undergo bioactivation to exert its toxic effects, including mutagenicity/carcinogenicity, obviously identifying the specific $\mathrm{BD}$ metabolite(s) that dominantly contribute to the toxic effects, particularly in humans, is at the core of the underlying molecular mechanisms of BD toxicity. However, so far the issue has not been addressed, largely because the metabolism of $\mathrm{BD}$ is quite complex and more than 10 potential metabolites, most of which are genotoxic, can be formed [1, 101, 102]. Making matters worse, each of the major metabolites, e.g., EB, DEB, EBD, and $\mathrm{CHB}$, contains stereoisomers due to the presence of chiral carbon atoms in these molecules, and importantly, the stereoisomers can have different bioactivity (e.g., cytotoxicity and mutagenicity) $[6,7,94,99]$. In addition, the metabolism of $\mathrm{BD}$ 
has great species difference $[1,6,7]$, leading to extra difficulty for studies on humans. Nonetheless, addressing the issue should be a major research direction for future studies.

Currently, it is generally assumed that mutagenicity/ carcinogenicity of $\mathrm{BD}$ is caused by the epoxide metabolites formed via the P450-mediated metabolism. Interestingly, all epidemiological studies that have been published so far have not discovered any associations between BD exposure and cancers of lung, liver, and kidney, the major organs that are responsible for uptake and biotransformation of $\mathrm{BD}$. Counterintuitively, the target organ for BD carcinogenicity in humans is the lymphohematopoietic system, an organ that seems not to be involved in the formation of P450-mediated epoxides. Why BD is not carcinogenic in the major human organs for uptake and metabolism is an intriguing issue. While extrahepatic toxicity is a likely explanation, the MPOmediated metabolic pathway seems to provide an attractive alternate because the pathway is expected to occur exactly in the lymphohematopoietic system. Addressing the issue is an important research direction because it concerns the molecular mechanisms of BD mutagenicity/carcinogenicity and can have significant impact on the risk assessment of BD.

Although having been studied for 40 years, our understanding of the molecular mechanisms of BD toxicity has still been limited. Besides the associations with diseases that have been discovered, it is likely that BD contributes to other adverse effects on human health or the etiology of other diseases, in particular, as a factor to promote disease progression rather than as a diseaseinitiating factor. Considering that $\mathrm{BD}$ is a ubiquitous pollutant, the direction deserves more attention.

\section{Conclusions}

$\mathrm{BD}$ is a ubiquitous environmental mutagen/carcinogen with high cancer risk. Its major environmental sources include automobile exhaust and tobacco smoke. The studies over the last decade have shown that microenvironments, particularly indoor microenvironments, are the primary determinant of exposure of the general population to $\mathrm{BD}$, with tobacco smoke being the main source. While it has been known for more than 20 years that occupational exposure to $\mathrm{BD}$ is associated with leukemia and CVD, recent progress shows that nonoccupational exposure to $\mathrm{BD}$ may be associated with certain reproductive effects, and more importantly, with several childhood cancers, autism, and asthma. The adverse effects on children's health need special attention and more studies.

\section{Abbreviations}

ADH: alcohol dehydrogenase; ALL: acute lymphocytic leukemia; AML: acute myeloid leukemia; BD: 1,3-butadiene; BDD: 3-butene-1,2-diol; bis-BDMA: 1,4-
bis(N-acetyl-L-cystein-S-yl)butane-2,3-diol; bis-N7G-BD: 1,4-bis(gua-7-yl)-2,3butanediol; CBMN: cytokinesis-block micronucleus; CBO: 1-chloro-2-buten-2one; CEB: 1-chloro-3,4-epoxy-2-butanol; CHB: 1-chloro-2-hydroxy-3-butene; $\mathrm{Cl}$ : confidence interval; CPD: cigarettes smoked per day; CVD: cardiovascular disease; DEB: 1,2,3,4-diepoxybutane; DHBMA: N-acetyl-S-(3,4-dihydroxybutyl)L-cysteine; EB: 3,4-epoxy-1-butene; EB-GI: N7-(2-hydroxy-3-buten-1-yl)guanine; EB-GII: N7-[1-(hydroxymethyl)-2-propen-1-yl]guanine; EBD: 3,4-epoxybutane1,2-diol; EPA: the U.S. Environmental Protection Agency; ETS: environmental tobacco smoke; GCTs: germ cell tumors; GSH: glutathione; HAPs: hazardous air pollutants; HMVK: hydroxymethyl vinyl ketone; HPRT: hypoxanthineguanine phosphoribosyltransferase; IARC: the International Agency for Research on Cancer; IQR: interquartile range; LOD: limit of detection; MHBMA: monohydroxybutenyl mercapturic acid; MHBMA1: N-acetyl-S-[1(hydroxymethyl)-2-propen-1-yl]-L-cysteine; MHBMA2: N-acetyl-S-(2-hydroxy-3buten-1-yl)-L-cysteine; MHBMA3: N-acetyl-S-(4-hydroxy-2-buten-1-yl)-Lcysteine; MN: micronucleus; MPO: myeloperoxidase; NAC: N-acetyl-L-cysteine; NC1:: 1,4-bis(N-acetyl-L-cystein-S-yl)-2-butanone; NNK: 4-(methylnitrosamino)1-(3-pyridyl)-1-butanone; NPB: nucleoplasmic bridge; OR: odds ratio; P450s: cytochrome P450 enzymes; PBL: peripheral blood lymphocytes; PNET: primitive neuroectodermal tumor; RR: rate ratio; SCE: sister-chromatid exchange; SMR: standardized mortality ratio; TBW: term birth weight; THBMA: N-acetyl-S-(2,3,4-trihydroxybutyl)-L-cysteine; VOCs: volatile organic compounds

\section{Acknowledgements}

We thank Professor Yang Luan for inviting us to submit a manuscript for the special collection in the Genes and Environment journal.

\section{Authors' contributions}

Both authors wrote the paper. Each author read and approved the final manuscript.

\section{Funding}

Research related to this review was supported by the National Nature Science Foundation of China (Nos. 21077070, 21377080, and 21976120) and the Shanghai Municipal Education Commission (No. 11ZZ90).

Availability of data and materials

Not applicable.

\section{Declarations}

Ethics approval and consent to participate

Not applicable.

Consent for publication

Not applicable.

\section{Competing interests}

The authors declare that they have no competing interests.

Received: 6 August 2021 Accepted: 27 December 2021

Published online: 10 January 2022

\section{References}

1. U.S. EPA. Health assessment of 1,3-butadiene. National Center for Environmental Assessment, Washington, DC, 2002. EPA/600/P-98/001F. Available at http://cfpub.epa.gov/ncea/cfm/recordisplay.cfm?deid=54499 (accessed August 6, 2021).

2. IARC. IARC Monographs on the Evaluation of Carcinogenic Risks to Humans, Vol. 97. 1,3-Butadiene, Ethylene Oxide and Vinyl Halides (Vinyl Fluoride, Vinyl Chloride and Vinyl Bromide). Lyon, France, 2008.

3. U.S. EPA. Initial List of Hazardous Air Pollutants with Modifications. Available at https://www.epa.gov/haps/initial-list-hazardous-air-pollutants-modifica tions (accessed August 6, 2021).

4. IARC. IARC Monographs on the Evaluation of Carcinogenic Risks to Humans, vol. 100F. France: Chemical Agents and Related Occupations. Lyon; 2012.

5. Hurst HE. Toxicology of 1,3-butadiene, chloroprene, and isoprene. Rev Environ Contam Toxicol. 2007;189:131-79. https://doi.org/10.1007/978-0-3 87-35368-5_6. 
6. Kirman CR, Albertini RJ, Sweeney LM, Gargas ML. 1,3-Butadiene: I. Review of metabolism and the implications to human health risk assessment. Crit Rev Toxicol. 2010;40(S1):1-11. https://doi.org/10.3109/10408444.2010.507181.

7. Albertini RJ, Carson ML, Kirman CR, Gargas ML. 1,3-Butadiene: II. Genotoxicity profile. Crit Rev Toxicol. 2010;40(S1):12-73. https://doi.org/10.31 09/10408444.2010.507182.

8. Kirman CR, Albertini RA, Gargas ML. 1,3-Butadiene: III. Assessing carcinogenic modes of action. Crit Rev Toxicol. 2010;40(S1):74-92. https://doi.org/10.31 09/10408444.2010.507183.

9. Ye Y, Galbally IE, Weeks IA. Emission of 1,3-butadiene from petrol-driven motor vehicles. Atmos Environ. 1997;31(8):1157-65. https://doi.org/10.1016/ S1352-2310(96)00308-1.

10. Zhang Y, Yang W, Simpson I, Huang X, Yu J, Huang Z, et al. Decadal changes in emissions of volatile organic compounds (VOCs) from on-road vehicles with intensified automobile pollution control: case study in a busy urban tunnel in south China. Environ Pollut. 2018;233:806-19. https://doi. org/10.1016/j.envpol.2017.10.133.

11. DRr C, Shah SD, Johnson KC, Zhu X, Miller JW, Orbeck JM. Development and application of a mobile laboratory for measuring emissions from diesel engines. 2. Sampling for toxics and particulate matter. Environ Sci Technol. 2004;38(24):6809-16. https://doi.org/10.1021/es049784x.

12. Yang J, Roth P, Durbin TD, Shafer MM, Hemming J, Antkiewicz DS, et al. Emissions from a flex fuel GDI vehicle operating on ethanol fuels show marked contrasts in chemical, physical and toxicological characteristics as a function of ethanol content. Sci Total Environ. 2019;683:749-61. https://doi. org/10.1016/j.scitotenv.2019.05.279.

13. Ghadikolaei MA, Wei $L$, Cheung CS, Yung KF. Effects of engine load and biodiesel content on performance and regulated and unregulated emissions of a diesel engine using contour-plot map. Sci Total Environ. 2019;658:1117-30. https://doi.org/10.1016/j.scitotenv.2018.12.270.

14. HEl Air Toxics Review Panel. Mobile-source air toxics: a critical review of the literature on exposure and health effects. HEI Special Report 16. Health Effects Institute, Boston, MA, 2007.

15. Smith CJ, Perfetti TA, Rumple MA, Rodgman A, Doolittle DJ. "IARC Group 2A Carcinogens" reported in cigarette mainstream smoke. Food Chem Toxicol. 2000;38(4):371-83. https://doi.org/10.1016/s0278-6915(99)00156-8.

16. Sampson MM, Chambers DM, Pazo DY, Moliere F, Blount BC, Watson CH. Simultaneous analysis of 22 volatile organic compounds in cigarette smoke using gas sampling bags for high-throughput solid-phase microextraction. Anal Chem. 2014;86(14):7088-95. https://doi.org/10.1021/ac5015518.

17. Hawke J, Errington G, von Frowein MB. Evaluation of an online, real-time, soft-photon ionisation time-of-flight mass spectrometer for mainstream tobacco smoke analysis. BMC Chem. 2019;13(1):135. https://doi.org/10.1186/ s13065-019-0654-z

18. Brunnemann KD, Kagan MR, Cox JE, Hoffmann D. Analysis of 1,3-butadiene and other selected gas-phase components in cigarette mainstream and sidestream smoke by gas chromatography-mass selective detection. Carcinogenesis. 1990;11(10):1863-8. https://doi.org/10.1093/carcin/11.10.1 863.

19. Oladipupo OA, Dutta D, Chong NS. Analysis of chemical constituents in mainstream bidi smoke. BMC Chem. 2019;13(1):93. https://doi.org/10.1186/ s13065-019-0614-7.

20. Vu AT, Hassink MD, Taylor KM, McGuigan M, Blasiole A, Valentin-Blasini L, et al. Volatile organic compounds in mainstream smoke of sixty domestic little cigar products. Chem Res Toxicol. 2021;34(3):704-12. https://doi.org/1 0.1021 /acs.chemrestox.0c00215.

21. Shields PG, Xu GX, Blot WJ, Fraumeni JFJ, Trivers GE, Pellizzari ED, et al. Mutagens from heated Chinese and U.S. cooking oils. J Natl Cancer Inst. 1995;87(11):836-41. https://doi.org/10.1093/jnci/87.11.836.

22. Pellizzari ED, Michael LC, Thomas KW, Shields PG, Harris CM. Identification of 1,3-butadiene, benzene, and other volatile organics from wok oil emissions. J Expo Anal Environ Epidemiol. 1995;5(1):77-87.

23. Huang X, Han D, Cheng J, Chen X, Zhou Y, Liao H, et al. Characteristics and health risk assessment of volatile organic compounds (VOCs) in restaurants in Shanghai. Environ Sci Pollut Res. 2020;27(1):490-9. https://doi.org/10.1 007/s11356-019-06881-6.

24. Xiong Y, Zhou J, Xing Z, Du K. Cancer risk assessment for exposure to hazardous volatile organic compounds in Calgary, Canada. Chemosphere. 2021;272:129650. https://doi.org/10.1016/j.chemosphere.2021.129650.
25. Zhao D, Wang X, Miller JB, Huber GW. The chemistry and kinetics of polyethylene pyrolysis: a process to produce fuels and chemicals. ChemSusChem. 2020;13(7):1764-74. https://doi.org/10.1002/cssc.201903434.

26. Hoffman E, Guernsey JR, Walker TR, Kim JS, Sherren K, Andreou P. Pilot study investigating ambient air toxics emissions near a Canadian kraft pulp and paper facility in Pictou County, Nova Scotia. Environ Sci Pollut Res. 2017;24(25):20685-98. https://doi.org/10.1007/s11356-017-9719-5.

27. Wang Y, Li L, Qiu Z, Yang K, Han Y, Chai F, et al. Trace volatile compounds in the air of domestic waste landfill site: Identification, olfactory effect and cancer risk. Chemosphere. 2021;272:129582. https://doi.org/10.1016/j. chemosphere.2021.129582

28. Ko HS, Jeong SB, Phyo S, Lee J, Jung JH. Emission of particulate and gaseous pollutants from household laser processing machine. J Environ Sci. 2021;103:148-56. https://doi.org/10.1016/j.jes.2020.10.018.

29. Kocher GJ, Sesia SB, Lopez-Hilfiker F, Schmid RA. Surgical smoke: still an underestimated health hazard in the operating theatre. Eur J Cardiothorac Surg. 2019;55(4):626-31. https://doi.org/10.1093/ejcts/ezy356.

30. Oganesyan G, Eimpunth S, Kim SS, Jiang SIB. Surgical smoke in dermatologic surgery. Dermatol Surg. 2014;40(12):1373-7. https://doi.org/1 0.1097/DSS.0000000000000221.

31. Cheng M-H, Chiu C-H, Chen C-T, Chou H-H, Pao L-H, Wan G-H. Sources and components of volatile organic compounds in breast surgery operating rooms. Ecotoxicol Environ Saf. 2021;209:111855. https://doi.org/10.1016/j. ecoenv.2020.111855.

32. Bree $K$, Barnhill S, Rundell W. The dangers of electrosurgical smoke to operating room personnel: a review. Workplace Health Saf. 2017;65(11):51726. https://doi.org/10.1177/2165079917691063.

33. Huang $X$, Lai J, Liu Y, Zheng L, Fang X, Song W, et al. Biogenic volatile organic compound emissions from Pinus massoniana and Schima superba seedlings: their responses to foliar and soil application of nitrogen. Sci Total Environ. 2020;705:135761. https://doi.org/10.1016/j.scitotenv.2019.135761.

34. Tahir HAS, Gu Q, Wu H, Niu Y, Huo R, Gao X. Bacillus volatiles adversely affect the physiology and ultra-structure of Ralstonia solanacearum and induce systemic resistance in tobacco against bacterial wilt. Sci Rep. 2017;7: 40481. https://doi.org/10.1038/srep40481.

35. Curren KC, Dann TF, Wang DK. Ambient air 1,3-butadiene concentrations in Canada (1995-2003): seasonal, day of week variations, trends, and source influences. Atmos Environ. 2006;40(1):170-81. https://doi.org/10.1016/j.a tmosenv.2005.09.025.

36. Kimbrough S, Palma T, Baldauf RW. Analysis of mobile source air toxics (MSATs)--Near-road VOC and carbonyl concentrations. J Air Waste Manag Assoc. 2014;64(3):349-59. https://doi.org/10.1080/10962247.2013.863814.

37. Simpson IJ, Marrero JE, Batterman S, Meinardi S, Barletta B, Blake DR. Air quality in the Industrial Heartland of Alberta, Canada and potential impacts on human health. Atmos Environ. 2013;81:702-9. https://doi.org/10.1016/j.a tmosenv.2013.09.017.

38. Scarselli A, Corfiati M, Di Marzio D, lavicoli S. Appraisal of levels and patterns of occupational exposure to 1,3-butadiene. Scand J Work Environ Health. 2017;43(5):494-503. https://doi.org/10.5271/sjweh.3644.

39. Gallego E, Roca FJ, Perales JF, Gadea E. Outdoor air 1,3-butadiene monitoring near a petrochemical industry (Tarragona region) and in several Catalan urban areas using active multi-sorbent bed tubes and analysis through TD-GC/MS. Sci Total Environ. 2018:618:1440-8. https://doi.org/10.1 016/j.scitotenv.2017.09.280.

40. Vallecillos L, Espallargas E, Allo R, Marcé RM, Borrull F. Passive sampling of volatile organic compounds in industrial atmospheres: uptake rate determinations and application. Sci Total Environ. 2019;666:235-44. https:// doi.org/10.1016/j.scitotenv.2019.02.213.

41. Huy LN, Lee SC, Zhang Z. Human cancer risk estimation for 1,3-butadiene: an assessment of personal exposure and different microenvironments. Sci Total Environ. 2018;616-617:1599-611. https://doi.org/10.1016/j.scitotenv.201 7.10.152.

42. U.S. EPA. Toxicological profile for 1,3-butadiene. U.S. Department of Health and Human Services, Public Health Service, Agency for Toxic Substances and Disease Registry, Atlanta, Georgia, 2012. Available at https://www.atsdr. cdc.gov/ToxProfiles/tp28.pdf (accessed August 6, 2021).

43. Pratt GC, Palmer K, Wu CY, Oliaei F, Hollerbach C, Fenske MJ. An assessment of air toxics in Minnesota. Environ Health Perspect. 2000;109(9):815-25. https://doi.org/10.1289/ehp.00108815.

44. Konkle SL, Zierold KM, Taylor KC, Riggs DW, Bhatnagar A. National secular trends in ambient air volatile organic compound levels and biomarkers of 
exposure in the United States. Environ Res. 2020;182:108991. https://doi. org/10.1016/j.envres.2019.108991.

45. Strum M, Scheffe R. National review of ambient air toxics observations. J Air Waste Manag Assoc. 2016;66(2):120-33. https://doi.org/10.1080/10962247.2 015.1076538 .

46. Propper R, Wong P, Bui S, Austin J, Vance W, Alvarado Á, et al. Ambient and emission trends of toxic air contaminants in California. Environ Sci Technol. 2015;49:11329-39. https://doi.org/10.1021/acs.est.5b02766.

47. Myers JL, Phillips T, Grant RL. Emissions and ambient air monitoring trends of lower olefins across Texas from 2002 to 2012. Chem Biol Interact. 2015; 241:2-9. https://doi.org/10.1016/j.cbi.2015.02.008.

48. Fujita EM, Campbell DE, Arnott WP, Johnson T, Ollison W. Concentrations of mobile source air pollutants in urban microenvironments. J Air Waste Manag Assoc. 2014;64(7):743-58. https://doi.org/10.1080/10962247.2013.872708.

49. Navasumrit $P$, Arayasiri M, Hiang OMT, Leechawengwongs M, Promvijit J Choonvisase $S$, et al. Potential health effects of exposure to carcinogenic compounds in incense smoke in temple workers. Chem Biol Interact. 2008; 173(1):19-31. https://doi.org/10.1016/j.cbi.2008.02.004.

50. Kim YM, Harrad S, Harrison RM. Concentrations and sources of VOCs in urban domestic and public microenvironments. Environ Sci Technol. 2001; 35(6):997-1004. https://doi.org/10.1021/es000192y.

51. Sleiman M, Logue JM, Luo W, Pankow JF, Gundel LA, Destaillats H. Inhalable constituents of thirdhand tobacco smoke: chemical characterization and health impact considerations. Environ Sci Technol. 2014;48(22):13093-101. https://doi.org/10.1021/es5036333.

52. McNabola A, Broderick B, Johnston P, Gill L. Effects of the smoking ban on benzene and 1,3-butadiene levels in pubs in Dublin. J Environ Sci Health A. 2006;41(5):799-810. https://doi.org/10.1080/10934520600614413.

53. Sadeghi-Yarandi M, Karimi A, Ahmadi V, Sajedian AA, Soltanzadeh A, Golbabaei F. Cancer and non-cancer health risk assessment of occupational exposure to 1,3-butadiene in a petrochemical plant in Iran. Toxicol Ind Health. 2020;36(12):960-70. https://doi.org/10.1177/0748233720962238.

54. Akerstrom M, Almerud P, Andersson EM, Strandberg B, Sallsten G. Personal exposure to benzene and 1,3-butadiene during petroleum refinery turnarounds and work in the oil harbour. Int Arch Occup Environ Health. 2016;89(8):1289-97. https://doi.org/10.1007/s00420-016-1163-1.

55. Almerud P, Akerstrom M, Andersson EM, Strandberg B, Sallsten G. Low personal exposure to benzene and 1,3-butadiene in the Swedish petroleum refinery industry. Int Arch Occup Environ Health. 2017;90(7):713-24. https:// doi.org/10.1007/s00420-017-1234-y.

56. Kampeerawipakorn O, Navasumrit P, Settachan D, Promvijit J, Hunsonti P, Parnlob V, et al. Health risk evaluation in a population exposed to chemical releases from a petrochemical complex in Thailand. Environ Res. 2017;152: 207-13. https://doi.org/10.1016/j.envres.2016.10.004.

57. Yan Y, Peng L, Cheng N, Bai H, Mu L. Health risk assessment of toxic VOCs species for the coal fire well drillers. Environ Sci Pollut Res. 2015;22:1513244. https://doi.org/10.1007/s11356-015-4729-7.

58. Sjöström M, Julander A, Strandberg B, Lewné M, Bigert C. Airborne and dermal exposure to polycyclic aromatic hydrocarbons, volatile organic compounds, and particles among firefighters and police investigators. Ann Work Expo Health. 2019;63(5):533-45. https://doi.org/10.1093/annweh/wxz030.

59. Louis LM, Kavi LK, Boyle M, Pool W, Bhandari D, De Jesús VR, et al. Biomonitoring of volatile organic compounds (VOCs) among hairdressers in salons primarily serving women of color: a pilot study. Environ Int. 2021;154: 106655. https://doi.org/10.1016/j.envint.2021.106655.

60. Kim YM, Harrad S, Harrison RM. Levels and sources of personal inhalation exposure to volatile organic compounds. Environ Sci Technol. 2002;36(24): 5405-10. https://doi.org/10.1021/es010148y.

61. Du Z, Mo J, Zhang Y. Risk assessment of population inhalation exposure to volatile organic compounds and carbonyls in urban China. Environ Int 2014;73:33-45. https://doi.org/10.1016/j.envint.2014.06.014.

62. Aquilina NJ, Delgado-Saborit JM, Meddings C, Baker S, Harrison RM, Pr J, et al. Environmental and biological monitoring of exposures to PAHs and ETS in the general population. Environ Int. 2010;36(7):763-71. https://doi. org/10.1016/j.envint.2010.05.015.

63. Boyle EB, Viet SM, Wright DJ, Merrill LS, Alwis KU, Blount BC, et al. Assessment of exposure to VOCs among pregnant women in the National Children's Study. Int J Environ Res Public Health. 2016;13(4):376. https://doi. org/10.3390/ijerph13040376.

64. Nieto A, Zhang L, Bhandari D, Zhu W, Blount BC, De Jesús VR. Exposure to 1,3-butadiene in the U.S. population: National Health and Nutrition
Examination Survey 2011-2016. Biomarkers. 2021;26(4):371-83. https://doi. org/10.1080/1354750X.2021.1904000.

65. Nazaroff WM, Singer BC. Inhalation of hazardous air pollutants from environmental tobacco smoke in US residences. J Expo Anal Environ Epidemiol. 2004;14:S71-7. https://doi.org/10.1038/sj.jea.7500361.

66. Hecht SS, Seow A, Wang M, Wang R, Meng L, Koh W-P, et al. Elevated levels of volatile organic carcinogen and toxicant biomarkers in Chinese women who regularly cook at home. Cancer Epidemiol Biomarkers Prev. 2010;19(5): 1185-92. https://doi.org/10.1158/1055-9965.EPI-09-1291.

67. Huang H, Tornero-Velez R, Barzyk TM. Associations between sociodemographic characteristics and chemical concentrations contributing to cumulative exposures in the United States. J Expo Sci Environ Epidemiol. 2017;27:544-50. https://doi.org/10.1038/jes.2017.15

68. U.S. EPA. 1,3-Butadiene, CASRN 106-99-0. Integrated Risk Information System, U.S. Environmental Protection Agency, National Center for Environmental Assessment, Washington, DC, available at http://cfpub.epa. gov/ncea/iris/iris_documents/documents/subst/0139_summary.pdf (accessed Aug 6, 2021).

69. Yang $Y$, Ji D, Sun J, Wang Y, Yao D, Zhao S, et al. Ambient volatile organic compounds in a suburban site between Beijing and Tianjin: concentration levels, source apportionment and health risk assessment. Sci Total Environ. 2019;695:133889. https://doi.org/10.1016/j.scitotenv.2019.133889.

70. Huang Y, Su T, Wang L, Wang N, Xue Y, Dai W, et al. Evaluation and characterization of volatile air toxics indoors in a heavy polluted city of northwestern China in wintertime. Sci Total Environ. 2019;662:470-80. https://doi.org/10.1016/j.scitotenv.2019.01.250

71. Dhaini HR, Salameh T, Waked A, Sauvage S, Borbon A, Formenti P, et al. Quantitative cancer risk assessment and local mortality burden for ambient air pollution in an eastern Mediterranean city. Environ Sci Pollut Res. 2017; 24(16):14151-62. https://doi.org/10.1007/s11356-017-9000-y.

72. Xiong Y, Bari MA, Xing Z, Du K. Ambient volatile organic compounds (VOCs) in two coastal cities in western Canada: spatiotemporal variation, source apportionment, and health risk assessment. Sci Total Environ. 2020;706: 135970. https://doi.org/10.1016/j.scitotenv.2019.135970.

73. Yacovitch TI, Herndon SC, Roscioli JR, Floerchinger C, Knighton WB, Kolb CE. Air pollutant mapping with a mobile laboratory during the BEE-TEX field study. Environ Health Insights. 2015;9(S4):7-13. https://doi.org/10.4137/EHI. S15660.

74. Xie G, Chen H, Zhang F, Shang X, Zhan B, Zeng L, et al. Compositions, sources, and potential health risks of volatile organic compounds in the heavily polluted rural North China Plain during the heating season. Sci Total Environ. 2021;789:147956. https://doi.org/10.1016/j.scitotenv.2021.147956.

75. Ding Y, Lu J, Liu Z, Li W, Chen J. Volatile organic compounds in Shihezi, China, during the heating season: pollution characteristics, source apportionment, and health risk assessment. Environ Sci Pollut Res. 2020;27: 16439-50. https://doi.org/10.1007/s11356-020-08132-5.

76. Jia H, Gao S, Duan Y, Fu Q, Che X, Xu H, et al. Investigation of health risk assessment and odor pollution of volatile organic compounds from industrial activities in the Yangtze River Delta region, China. Ecotoxicol Environ Saf. 2021;208:111474. https://doi.org/10.1016/j.ecoenv.2020.111474.

77. Zheng H, Kong S, Yan Y, Chen N, Yao L, Liu X, et al. Compositions, sources and health risks of ambient volatile organic compounds (VOCs) at a petrochemical industrial park along the Yangtze River. Sci Total Environ. 2020;703:135505. https://doi.org/10.1016/j.scitotenv.2019.135505.

78. Mo Z, Shao M, Lu S, Qu H, Zhou M, Sun J, et al. Process-specific emission characteristics of volatile organic compounds (VOCs) from petrochemical facilities in the Yangtze River Delta, China. Sci Total Environ. 2015:533:42231. https://doi.org/10.1016/j.scitotenv.2015.06.089.

79. Loh MM, Levy JI, Spengler JD, Houseman EA, Bennett DH. Ranking cancer risks of organic hazardous air pollutants in the United States. Environ Health Perspect. 2007;115(8):1160-8. https://doi.org/10.1289/ehp.9884.

80. McCarthy MC, O'Brien TE, Charrier JG, Hafner HR. Characterization of the chronic risk and hazard of hazardous air pollutants in the United States using ambient monitoring data. Environ Health Perspect. 2009;117(5):790-6. https://doi.org/10.1289/ehp.11861.

81. Zhou J, You Y, Bai Z, Hu Y, Zhang J, Zhang N. Health risk assessment of personal inhalation exposure to volatile organic compounds in Tianjin, China. Sci Total Environ. 2011;409(3):452-9. https://doi.org/10.1016/j. scitotenv.2010.10.022.

82. Nakamura J, Carro S, Gold A, Zhang Z. An unexpected butadiene diolepoxide-mediated genotoxicity implies alternative mechanism for 1,3- 
butadiene carcinogenicity. Chemosphere. 2021;266:129149. https://doi.org/1 0.1016/j.chemosphere.2020.129149.

83. Wen Y, Zhang P-P, An J, Yu Y-X, Wu M-H, Sheng G-Y, et al. Diepoxybutane induces the formation of DNA-DNA rather than DNA-protein cross-links, and single-strand breaks and alkali-labile sites in human hepatocyte L02 cells. Mutat Res. 2011;716(1-2):84-91. https://doi.org/10.1016/j.mrfmmm.2011.08.007.

84. Zhang P-P, Wen Y, An J, Yu Y-X, Wu M-H, Zhang X-Y. DNA damage induced by three major metabolites of 1,3-butadiene in human hepatocyte L02 cells. Mutat Res. 2012;747(2):240-5. https://doi.org/10.1016/j.mrgentox.2012.06.001.

85. Fuccelli R, Sepporta MV, Rosignoli P, Morozzi G, Servili M, Fabiani R. Preventive activity of olive oil phenolic compounds on alkene epoxides induced oxidative DNA damage on human peripheral blood mononuclear cells. Nutr Cancer. 2014;66(8):1322-30. https://doi.org/10.1080/01635581.2 014.956251 .

86. Dong J, Wang Z, Zou P, Zhang G, Dong X, Ling X, et al. Induction of DNA damage and $G_{2}$ cell cycle arrest by diepoxybutane through the activation of the Chk1-dependent pathway in mouse germ cells. Chem Res Toxicol. 2015;28(3):518-31. https://doi.org/10.1021/t×500489r.

87. Walker VE, Walker DM, Meng Q, McDonald JD, Scott BR, Seilkop SK, et al. Genotoxicity of 1,3-butadiene and its epoxy intermediates. Res Rep Health Eff Inst. 2009;144:3-79.

88. Filser JG, Hutzler C, Meischner V, Veereshwarayya V, Csanády GA. Metabolism of 1,3-butadiene to toxicologically relevant metabolites in single-exposed mice and rats. Chem Biol Interact. 2007;166(1-3):93-103. https://doi.org/10.1016/j.cbi.2006.03.002.

89. Zhang X-Y, Elfarra AA. Identification and characterization of a series of nucleoside adducts formed by the reaction of 2'-deoxyguanosine and 1,2,3,4-diepoxybutane under physiological conditions. Chem Res Toxicol. 2003;16(12):1606-15. https://doi.org/10.1021/tx0341355.

90. Zhang X-Y, Elfarra AA. Characterization of the reaction products of 2'deoxyguanosine and 1,2,3,4-diepoxybutane after acid hydrolysis: formation of novel guanine and pyrimidine adducts. Chem Res Toxicol. 2004;17(4): 521-8. https://doi.org/10.1021/tx034243r.

91. Zhang X-Y, Elfarra AA. Reaction of 1,2,3,4-diepoxybutane with 2'deoxyguanosine: initial products and their stabilities and decomposition patterns under physiological conditions. Chem Res Toxicol. 2005;18(8):131623. https://doi.org/10.1021/tx0500979.

92. Park S, Tretyakova N. Structural characterization of the major DNA-DNA cross-link of 1,2,3,4-diepoxybutane. Chem Res Toxicol. 2004;17(2):129-36. https://doi.org/10.1021/tx0342058.

93. Park S, Hodge J, Anderson C, Tretyakova N. Guanine-adenine DNA crosslinking by 1,2,3,4-diepoxybutane: potential basis for biological activity. Chem Res Toxicol. 2004;17(12):1638-1651.

94. Park S, Anderson C, Loeber R, Seetharaman M, Jones R, Tretyakova N. Interstrand and intrastrand DNA-DNA cross-linking by 1,2,3,4-diepoxybutane: role of stereochemistry. J Am Chem Soc. 2005;127(41):14355-65. https://doi. org/10.1021/ja051979x

95. Goggin M, Swenberg JA, Walker VE, Tretyakova N. Molecular dosimetry of 1,2,3,4-diepoxybutane-induced DNA-DNA cross-links in B6C3F1 mice and F344 rats exposed to 1,3-butadiene by inhalation. Cancer Res. 2009;69(6): 2479-86. https://doi.org/10.1158/0008-5472.CAN-08-4152.

96. Zhang X-Y, Elfarra AA. Characterization of 1,2,3,4-diepoxybutane-2'deoxyguanosine cross-linking products formed at physiological and nonphysiological conditions. Chem Res Toxicol. 2006;19(4):547-55. https:// doi.org/10.1021/tx0503395.

97. Groehler A, Degner A, Tretyakova NY. Mass spectrometry-based tools to characterize DNA-protein cross-linking by bis-electrophiles. Basic Clin Pharmacol Toxicol. 2017;121(Suppl. 3):63-77. https://doi.org/10.1111/bcpt.12 751.

98. Morita T, Asano N, Awogi T, Sasaki YF, Sato S, Shimada H, et al. Evaluation of the rodent micronucleus assay in the screening of IARC carcinogens (groups 1, 2A and 2B) the summary report of the 6th collaborative study by CSGMT/JEMS MMS. Collaborative Study of the Micronucleus Group Test. Mammalian Mutagenicity Study Group. Mutat Res. 1997;389(1):3-122. https://doi.org/10.1016/s1383-5718(96)00070-8.

99. Meng RQ, Hackfeld LC, Hodge RP, Wisse LA, Redetzke DL, Walker VE. Mutagenicity of stereochemical configurations of 1,3-butadiene epoxy metabolites in human cells. Res Rep Health Eff Inst. 2010;150:1-34.

100. Duescher RJ, Elfarra AA. 1,3-Butadiene oxidation by human myeloperoxidase. J Biol Chem. 1992;267(28):19859-65.
101. Zhang X-Y, Elfarra AA. Potential roles of myeloperoxidase and hypochlorous acid in metabolism and toxicity of alkene hydrocarbons and drug molecules containing olefinic moieties. Expert Opin Drug Metab Toxicol. 2017;13(5):513-24. https://doi.org/10.1080/17425255.2017.1271413.

102. Zhang $X-Y$, Elfarra AA, editors. Myeloperoxidase-mediated bioactivation of olefins, vol 12. Cambridge, MA, USA: Advances in Molecular Toxicology. Academic Press; 2018.

103. Elfarra AA, Zhang X-Y. Alcohol dehydrogenase- and rat liver cytosoldependent bioactivation of 1-chloro-2-hydroxy-3-butene to 1-chloro-3buten-2-one, a bifunctional alkylating agent. Chem Res Toxicol. 2012;25(11): 2600-7. https://doi.org/10.1021/tx300369b.

104. Wu W-J, Tang W-F, Xiang M-H, Yan J, Cao X, Zhou C-H, Chang Y, Xi J, Cao Y-Y, Luan Y, Zhang X-Y. Isotope dilution LC/ESI-MS-MS quantitation of urinary 1,4-bis( $N$-acetyl-S-cysteinyl)-2-butanone in mice and rats as the biomarker of 1-chloro-2-hydroxy-3-butene, an in vitro metabolite of 1,3butadiene. Chem Biol Interact. 2019;311:108760. 10.1016/j.cbi.2019.108760.

105. Wang Y, Yu Y-X, Luan Y, An J, Yin D-G, Zhang X-Y. Bioactivation of 1-chloro2-hydroxy-3-butene, an in vitro metabolite of 1,3-butadiene, by rat liver microsomes. Chem Biol Interact. 2018;282:36-44. https://doi.org/10.1016/j. cbi.2018.01.006.

106. Sun L, Pelah A, Zhang D-P, Zhong Y-F, An J, Yu Y-X, et al. Formation of fused-ring 2'-deoxycytidine adducts from 1-chloro-3-buten-2-one, an in vitro 1,3-butadiene metabolite, under in vitro physiological conditions. Chem Res Toxicol. 2013;26(10):1545-53. https://doi.org/10.1021/tx4002435.

107. Zheng J, Li Y, Yu Y-X, An J, Zhang X-Y, Elfarra AA. Novel adducts from the reaction of 1-chloro-3-buten-2-one with 2'-deoxyguanosine. Structural characterization and potential as tools to investigate 1,3-butadiene carcinogenicity. Chem Biol Interact. 2015;226:40-8. https://doi.org/10.1016/j. cbi.2014.12.003.

108. Zeng F-M, Liu L-Y, Zheng J, Kong C, An J, Yu Y-X, et al. Identification of a fused-ring 2'-deoxyadenosine adduct formed in human cells incubated with 1-chloro-3-buten-2-one, a potential reactive metabolite of 1,3-butadiene. Chem Res Toxicol. 2016;29(6):1041-50. https://doi.org/10.1021/acs. chemrestox.6b00095.

109. Liu L-Y, Zheng J, Kong C, An J, Yu Y-X, Zhang X-Y, et al. Characterization of the major purine and pyrimidine adducts formed after incubations of 1chloro-3-buten-2-one with single-/double-stranded DNA and human cells. Chem Res Toxicol. 2017;30(2):552-63. https://doi.org/10.1021/acs. chemrestox.6b00282.

110. Liu X-J, Zeng F-M, An J, Yu Y-X, Zhang X-Y, Elfarra AA. Cytotoxicity, genotoxicity, and mutagenicity of 1-chloro-2-hydroxy-3-butene and 1 chloro-3-buten-2-one, two alternative metabolites of 1,3-butadiene. Toxicol Appl Pharmacol. 2013;271(1):13-9. https://doi.org/10.1016/j.taap.2013.04.019.

111. Liu B-L. Study of myeloperoxidase-mediated metabolites of 1,3-butadiene. MS Thesis: Shanghai University; 2017.

112. Chang SC, Seneviratne UI, Wu J, Tretyakova N, Essigmann JM. 1,3-Butadieneinduced adenine DNA adducts are genotoxic but only weakly mutagenic when replicated in Escherichia coli of various repair and replication backgrounds. Chem Res Toxicol. 2017;30(5):1230-9. https://doi.org/10.1021/a cs.chemrestox.7b00064.

113. Kotapati S, Sangaraju D, Esades A, Hallberg L, Walker VE, Swenberg JA, et al. Bis-butanediol-mercapturic acid (bis-BDMA) as a urinary biomarker of metabolic activation of butadiene to its ultimate carcinogenic species. Carcinogenesis. 2014;35(6):1371-8. https://doi.org/10.1093/carcin/bgu047.

114. Fred C, Törnqvist M, Granath F. Evaluation of cancer tests of 1,3-butadiene using internal dose, genotoxic potency, and a multiplicative risk model. Cancer Res. 2008;68(19):8014-21. https://doi.org/10.1158/0008-5472.CAN-080334.

115. Swenberg JA, Bordeerat NK, Boysen G, Carro S, Georgieva NI, Nakamura J, et al. 1,3-Butadiene: biomarkers and application to risk assessment. Chem Biol Interact. 2011;192(1-2):150-4. https://doi.org/10.1016/j.cbi.2010.10.010.

116. Boysen G, Georgieva NI, Bordeerat NK, Sram RJ, Vacek P, Albertini RJ, et al. Formation of 1,2:3,4-diepoxybutane-specific hemoglobin adducts in 1,3butadiene exposed workers. Toxicol Sci. 2012;125(1):30-40. https://doi.org/1 $0.1093 /$ toxsci/kfr272.

117. Motwani HV, Törnqvist M. In vivo doses of butadiene epoxides as estimated from in vitro enzyme kinetics by using cob(I) alamin and measured hemoglobin adducts: an inter-species extrapolation approach. Toxicol Appl Pharmacol. 2014;281(3):276-84. https://doi.org/10.1016/j.taap.2014.10.011. 
118. Hartley JA, O'Hare CC, Baumgart J. DNA alkylation and interstrand crosslinking by treosulfan. Br J Cancer. 1999;79(2):264-6. https://doi.org/10.1038/ sj.bjc.6690043.

119. Eastmond DA, Keshava N, Sonawane B. Lymphohematopoietic cancers induced by chemicals and other agents and their implications for risk evaluation: an overview. Mutat Res. 2014;761:40-64. https://doi.org/10.1016/ j.mrrev.2014.04.001.

120. Boysen G, Georgieva NI, Upton PB, Walker VE, Swenberg JA. N-terminal globin adducts as biomarkers for formation of butadiene derived epoxides. Chem Biol Interact. 2007;166(1-3):84-92. https://doi.org/10.1016/j.cbi.2006.10. 005 .

121. Swenberg JA, Koc H, Upton PB, Georguieva N, Ranasinghe A, Walker VE, et al. Using DNA and hemoglobin adducts to improve the risk assessment of butadiene. Chem Biol Interact. 2001;135-136:387-403. https://doi.org/10.1 016/s0009-2797(01)00221-6.

122. Bond JA, Dahl AR, Henderson RF, Dutcher JS, Mauderly JL, Birnbaum LS. Species differences in the disposition of inhaled butadiene. Toxicol Appl Pharmacol. 1986;84(3):617-27. https://doi.org/10.1016/0041-008x(86)90268-1.

123. Sun JD, Dahl AR, Bond JA, Birnbaum LS, Henderson RF. Metabolism of inhaled butadiene to monkeys: comparison to rodents. Exp Pathol. 1989; 37(1-4):133-5. https://doi.org/10.1016/s0232-1513(89)80032-5.

124. van Sittert NJ, Megens HJ, Watson WP, Boogaard PJ. Biomarkers of exposure to 1,3-butadiene as a basis for cancer risk assessment. Toxicol Sci. 2000; 56(1):189-202. https://doi.org/10.1093/toxsci/56.1.189

125. Sabourin PJ, Burka LT, Bechtold WE, Dahl AR, Hoover MD, Chang IY, et al. Species differences in urinary butadiene metabolites; identification of 1,2dihydroxy-4-(N-acetylcysteinyl) butane, a novel metabolite of butadiene. Carcinogenesis. 1992;13(9):1633-8. https://doi.org/10.1093/carcin/13.9.1633.

126. Elfarra AA, Sharer JE, Duescher RJ. Synthesis and characterization of Nacetyl-L-cysteine S-conjugates of butadiene monoxide and their detection and quantitation in urine of rats and mice given butadiene monoxide. Chem Res Toxicol. 1995;8(1):68-76. https://doi.org/10.1021/tx00043a009.

127. Richardson KA, Peters MM, Megens RH, van Elburg PA, Golding BT, Boogaard PJ, et al. Identification of novel metabolites of butadiene monoepoxide in rats and mice. Chem Res Toxicol. 1998;11(12):1543-55. https://doi.org/10.1021/tx970175v.

128. Richardson KA, Peters MM, Wong BA, Megens RH, van Elburg PA, Booth ED, et al. Quantitative and qualitative differences in the metabolism of ${ }^{14} \mathrm{C}-1,3-$ butadiene in rats and mice: relevance to cancer susceptibility. Toxicol Sci. 1999:49(2):186-201. https://doi.org/10.1093/toxsci/49.2.186.

129. Kotapati S, Matter BA, Grant AL, Tretyakova NY. Quantitative analysis of trihydroxybutyl mercapturic acid, a urinary metabolite of 1,3-butadiene, in humans. Chem Res Toxicol. 2011;24(9):1516-26. https://doi.org/10.1021/tx2 001306.

130. Sangaraju D, Boldry EJ, Patel YM, Walker V, Stepanov I, Stram D, et al. Isotope dilution nanoLC/ESI ${ }^{+}-\mathrm{HRMS}^{3}$ quantitation of urinary N7-(1-hydroxy3-buten-2-yl) guanine adducts in humans and their use as biomarkers of exposure to 1,3-butadiene. Chem Res Toxicol. 2017;30(2):678-88. https://doi. org/10.1021/acs.chemrestox.6b00407.

131. Erber L, Goodman S, Jokipii Krueger CC, Rusyn I, Tretyakova N. Quantitative NanoLC/NSI ${ }^{+}$-HRMS method for 1,3-butadiene induced bis-N7-guanine DNA-DNA cross-links in urine. Toxics. 2021;9(10):247. https://doi.org/10.3390/ toxics9100247.

132. Bechtold WE, Strunk MR, Chang IY, Ward JBJ, Henderson RF. Species differences in urinary butadiene metabolites: comparisons of metabolite ratios between mice, rats, and humans. Toxicol Appl Pharmacol. 1994;127(1): 44-9. https://doi.org/10.1006/taap.1994.1137.

133. Boogaard PJ, van Sittert NJ, Megens HJ. Urinary metabolites and haemoglobin adducts as biomarkers of exposure to 1,3-butadiene: a basis for 1,3-butadiene cancer risk assessment. Chem Biol Interact. 2001;135-136: 695-701. https://doi.org/10.1016/s0009-2797(01)00205-8.

134. Albertini RJ, Sram RJ, Vacek PM, Lynch J, Wright M, Nicklas JA, et al. Biomarkers for assessing occupational exposures to 1,3-butadiene. Chem Biol Interact. 2001;135-136:429-53. https://doi.org/10.1016/s0009-2797(01 )00181-8.

135. Kotapati S, Esades A, Matter B, Le C, Tretyakova N. High throughput HPLCESI'-MS/MS methodology for mercapturic acid metabolites of 1,3-butadiene: biomarkers of exposure and bioactivation. Chem Biol Interact. 2015;241:2331. https://doi.org/10.1016/j.cbi.2015.02.009.

136. Frigerio G, Mercadante $R$, Campo L, Polledri E, Boniardi L, Olgiati $L$, et al. Urinary biomonitoring of subjects with different smoking habits. Part I:
Profiling mercapturic acids. Toxicol Lett. 2020;327:48-57. https://doi.org/10.1 016/j.toxlet.2020.03.010.

137. Carmella SG, Chen M, Han S, Briggs A, Jensen J, Hatsukami DK, et al. Effects of smoking cessation on eight urinary tobacco carcinogen and toxicant biomarkers. Chem Res Toxicol. 2009;22(4):734-41. https://doi.org/10.1021/ tx800479s.

138. Schettgen T, Musiol A, Alt A, Ochsmann E, Kraus T. A method for the quantification of biomarkers of exposure to acrylonitrile and 1,3-butadiene in human urine by column-switching liquid chromatography-tandem mass spectrometry. Anal Bioanal Chem. 2009;393(3):969-81. https://doi.org/10.1 007/s00216-008-2510-1.

139. Alwis KU, Blount BC, Britt AS, Patel D, Ashley DL. Simultaneous analysis of 28 urinary VOC metabolites using ultra high performance liquid chromatography coupled with electrospray ionization tandem mass spectrometry (UPLC-ESI/MSMS). Anal Chim Acta. 2012;750:152-60. https:// doi.org/10.1016/j.aca.2012.04.009.

140. Chiang W-C, Chen C-Y, Lee T-C, Lee H-L, Lin Y-W. Fast and simple screening for the simultaneous analysis of seven metabolites derived from five volatile organic compounds in human urine using on-line solid-phase extraction coupled with liquid chromatography-tandem mass spectrometry. Talanta. 2015;132:469-78. https://doi.org/10.1016/j.talanta.2014.09.029.

141. Rostron BL, Corey CG, Chang JT, van Bemmel DM, Miller ME, Chang CM. Associations of cigarettes smoked per day with biomarkers of exposure among U.S. adult cigarette smokers in the Population Assessment of Tobacco and Health (PATH) Study Wave 1 (2013-2014). Cancer Epidemiol Biomarkers Prev. 2019;28(9):1443-53. https://doi.org/10.1158/1055-9965.EPI-1 9-0013.

142. De Jesús VR, Bhandari D, Zhang L, Reese C, Capella K, Tevis D, et al. Urinary biomarkers of exposure to volatile organic compounds from the Population Assessment of Tobacco and Health Study Wave 1 (2013-2014). Int J Environ Res Public Health. 2020;17(15):5408. https://doi.org/10.3390/ijerph17155408.

143. Carroll DM, Murphy SE, Benowitz NL, Strasser AA, Kotlyar M, Hecht SS, et al. Relationships between the nicotine metabolite ratio and a panel of exposure and effect biomarkers: findings from two studies of U.S. commercial cigarette smokers. Cancer Epidemiol Biomarkers Prev. 2020; 29(4):871-9. https://doi.org/10.1158/1055-9965.EPI-19-0644

144. Chung C-J, Hsu H-T, Chang C-H, Li S-W, Liu C-S, Chung M-C, et al. Relationships among cigarette smoking, urinary biomarkers, and urothelial carcinoma risk: a case-control study. Environ Sci Pollut Res. 2020;27(34): 43177-85. https://doi.org/10.1007/s11356-020-10196-2.

145. Etemadi A, Poustchi $H$, Calafat AM, Blount BC, De Jesús VR, Wang $L$, et al. Opiate and tobacco use and exposure to carcinogens and toxicants in the Golestan Cohort Study. Cancer Epidemiol Biomarkers Prev. 2020;29(3):650-8. https://doi.org/10.1158/1055-9965.EPI-19-1212

146. Travers MJ, Rivard C, Sharma E, Retzky S, Yucesoy B, Goniewicz ML, et al. Biomarkers of exposure among USA adult hookah users: results from Wave 1 of the Population Assessment of Tobacco and Health (PATH) Study (20132014). Int J Environ Res Public Health. 2020;17(17):6403. https://doi.org/10.33 90/ijerph17176403.

147. Rostron BL, Corey CG, Chang JT, van Bemmel DM, Miller ME, Chang CM. Changes in cigarettes per day and biomarkers of exposure among US adult smokers in the Population Assessment of Tobacco and Health Study Waves 1 and 2 (2013-2015). Nicotine Tob Res. 2020;22(10):1780-7. https://doi.org/1 $0.1093 /$ ntr/ntaa038.

148. McGraw KE, Riggs DW, Rai S, Navas-Acien A, Xie Z, Lorkiewicz P, et al. Exposure to volatile organic compounds - acrolein, 1,3-butadiene, and crotonaldehyde - is associated with vascular dysfunction. Environ Res. 2021; 196:110903. https://doi.org/10.1016/j.envres.2021.110903.

149. Jain RB. Distributions of selected urinary metabolites of volatile organic compounds by age, gender, race/ethnicity, and smoking status in a representative sample of U.S. adults. Environ Toxicol Pharmacol. 2015;40: 471-9. https://doi.org/10.1016/j.etap.2015.07.018.

150. Jain RB. Levels of selected urinary metabolites of volatile organic compounds among children aged 6-11 years. Environ Res. 2015;142:461-70. https://doi.org/10.1016/j.envres.2015.07.023.

151. Etemadi A, Poustchi $H$, Chang CM, Blount BC, Calafat AM, Wang L, De Jesús VR, Pourshams A, Shakeri R, Shiels MS, Inoue-Choi M, Ambrose BK, Christensen CH, Wang B, Murphy G, Ye X, Bhandari D, Feng J, Xia B, Sosnoff CS, Kamangar F, Brennan P, Boffetta P, Dawsey SM, Abnet CC, Malekzadeh $\mathrm{R}$, Freedman ND. Urinary biomarkers of carcinogenic exposure among cigarette, waterpipe, and smokeless tobacco users and never users of 
tobacco in the Golestan Cohort Study. Cancer Epidemiol Biomarkers Prev. 2019:28(2):337-347. 10.1158/1055-9965.EPI-18-0743.

152. Qian X, Wan Y, Wang A, Xia W, Yang Z, He Z, et al. Urinary metabolites of multiple volatile organic compounds among general population in Wuhan, central China: inter-day reproducibility, seasonal difference, and their associations with oxidative stress biomarkers. Environ Pollut. 2021;289: 117913. https://doi.org/10.1016/j.envpol.2021.117913.

153. Kuang H, Li Y, Jiang W, Wu P, Tan J, Zhang H, et al. Simultaneous determination of urinary 31 metabolites of VOCs, 8-hydroxy-2'deoxyguanosine, and trans-3'-hydroxycotinine by UPLC-MS/MS: ${ }^{13} \mathrm{C}$ - and ${ }^{15} \mathrm{~N}$-labeled isotoped internal standards are more effective on reduction of matrix effect. Anal Bioanal Chem. 2019;411(29):7841-55. https://doi.org/10.1 007/s00216-019-02202-5.

154. St Helen G, Pr J, Peng M, Dempsey DA, Hammond SK, Benowitz NL. Intake of toxic and carcinogenic volatile organic compounds from secondhand smoke in motor vehicles. Cancer Epidemiol Biomarkers Prev. 2014;23(12): 2774-82. https://doi.org/10.1158/1055-9965.EPI-14-0548.

155. Nauhaus SK, Fennell TR, Asgharian B, Bond JA, Sumner SCJ. Characterization of urinary metabolites from Sprague-Dawley rats and B6C3F1 mice exposed to $\left[1,2,3,4-{ }^{13} \mathrm{C}\right]$ butadiene. Chem Res Toxicol. 1996;9(4):764-73. https://doi. org/10.1021/tx950196u.

156. Liu B, Zhang X. Reaction of 1-chloro-3-buten-2-one with N-acetylcysteine. J Shanghai Univ. 2018;24(1):74-82. 10.12066/j.issn.1007-2861.1846.

157. Tretyakova NY, Chiang S-Y, Walker VE, Swenberg JA. Quantitative analysis of 1,3-butadiene-induced DNA adducts in vivo and in vitro using liquid chromatography electrospray ionization tandem mass spectrometry. J Mass Spectrom. 1998:33(4):363-76. https://doi.org/10.1002/(SICI)1096-9888(199804 )33:4<363::AID-JMS643>3.0.CO;2-E.

158. Sangaraju D, Villalta PW, Wickramaratne S, Swenberg J, Tretyakova N. NanoLC/ESI ${ }^{+} \mathrm{HRMS}^{3}$ quantitation of DNA adducts induced by 1,3butadiene. J Am Soc Mass Spectrom. 2014;25(7):1124-35. https://doi.org/1 0.1007/s13361-014-0916-X.

159. Jokipii Krueger CC, Madugundu G, Degner A, Patel Y, Stram DO, Church TR, et al. Urinary N7-(1-hydroxy-3-buten-2-yl) guanine adducts in humans: temporal stability and association with smoking. Mutagenesis. 2020;35(1): 19-26. https://doi.org/10.1093/mutage/gez030.

160. Jokipii Krueger CC, Park SL, Madugundu G, Patel Y, Le Marchand L, Stram DO, et al. Ethnic differences in excretion of butadiene-DNA adducts by current smokers. Carcinogenesis. 2021;42(5):694-704. https://doi.org/10.1 093/carcin/bgab020.

161. Erber L, Goodman S, Wright FA, Chiu WA, Tretyakova NY, Rusyn I. Intra- and inter-species variability in urinary N7-(1-hydroxy-3-buten-2-yl) guanine adducts following inhalation exposure to 1,3-butadiene. Chem Res Toxicol. 2021;34(11):2375-83. https://doi.org/10.1021/acs.chemrestox.1c00291.

162. Carrieri M, Bartolucci GB, Paci E, Sacco P, Pigini D, Zaratin L, et al. Validation of a radial diffusive sampler for measuring occupational exposure to 1,3butadiene. J Chromatogr A. 2014;1353:114-20. https://doi.org/10.1016/j. chroma.2014.02.018.

163. Tan H, Wang Q, Wang A, Ye Y, Feng N, Feng X, et al. Influence of GSTS, CYP2E1 and $m E H$ polymorphisms on 1, 3-butadiene-induced micronucleus frequency in Chinese workers. Toxicol Appl Pharmacol. 2010;247(3):198-203. https://doi.org/10.1016/j.taap.2010.07.006.

164. Cheng X, Zhang T, Zhao J, Zhou J, Shao H, Zhou Z, et al. The association between genetic damage in peripheral blood lymphocytes and polymorphisms of three glutathione S-transferases in Chinese workers exposed to 1,3-butadiene. Mutat Res. 2013;750(1-2):139-46. https://doi.org/1 0.1016/j.mrgentox.2012.10.008.

165. Xiang M, Ao L, Yang H, Liu W, Sun L, Han X, et al. Chromosomal damage and polymorphisms of metabolic genes among 1,3-butadiene-exposed workers in a matched study in China. Mutagenesis. 2012;27(4):415-21. https://doi.org/10.1093/mutage/ger091.

166. Xiang M, Sun L, Dong X, Yang H, Liu W-B, Zhou N, et al. Association between genetic polymorphisms of DNA repair genes and chromosomal damage for 1,3-butadiene-exposed workers in a matched study in China. Biomed Res Int. 2015;2015:234675. https://doi.org/10.1155/2015/234675.

167. Xiang M, Wang Z, Zou P, Ling X, Zhang G, Zhou Z, et al. Folate metabolism modifies chromosomal damage induced by 1,3-butadiene: results from a match-up study in China and in vitro experiments. Genes Environ. 2021; 43(1):44. https://doi.org/10.1186/s41021-021-00217-y.

168. Federico C, Vitale V, La Porta N, Saccone S. Buccal micronucleus assay in human populations from Sicily (Italy) exposed to petrochemical industry pollutants. Environ Sci Pollut Res. 2019;26(7):7048-54. https://doi.org/10.1 007/s11356-019-04193-3.

169. Bolognesi C, Kirsch-Volders M. The ex vivo L-CBMN assay detects significant human exposure to butadiene. Mutat Res. 2016;770(Pt A):73-83. https://doi. org/10.1016/j.mrrev.2016.04.001.

170. Sielken RL Jr, Valdez-Flores C. A comprehensive review of occupational and general population cancer risk: 1,3-butadiene exposure-response modeling for all leukemia, acute myelogenous leukemia, chronic lymphocytic leukemia, chronic myelogenous leukemia, myeloid neoplasm and lymphoid neoplasm. Chem Biol Interact. 2015;241:50-8. https://doi.org/10.1016/j.cbi.2 015.06.009.

171. Sathiakumar N, Brill I, Leader M, Delzell E. 1,3-Butadiene, styrene and lymphohematopoietic cancer among male synthetic rubber industry workers - preliminary exposure-response analyses. Chem Biol Interact. 2015; 241:40-9. https://doi.org/10.1016/j.cbi.2015.09.003.

172. Sathiakumar N, Tipre M, Leader M, Brill I, Delzell E. Mortality among men and women in the North American synthetic rubber industry, 1943 to 2009. J Occup Environ Med. 2019;61(11):887-97. https://doi.org/10.1097/JOM. 0000000000001688.

173. Sathiakumar N, Bolaji BE, Brill I, Chen L, Tipre M, Leader M, Arora T, Delzell E. 1,3-Butadiene, styrene and lymphohaematopoietic cancers among North American synthetic rubber polymer workers: exposure-response analyses. Occup Environ Med. 2021;Jun. 9. https://doi.org/10.1136/oemed-2020-1071 97.

174. Divine BJ. An update on mortality among workers at a 1,3-butadiene facility-preliminary results. Environ Health Perspect. 1990;86:1 19-28. https:// doi.org/10.1289/ehp.9086119.

175. Matanoski GM, Santos-Burgoa C, Schwartz L. Mortality of a cohort of workers in the styrene-butadiene polymer manufacturing industry (19431982). Environ Health Perspect. 1990;86:107-17. https://doi.org/10.1289/ehp. 9086107.

176. Divine BJ, Hartman CM. Mortality update of butadiene production workers. Toxicology. 1996;113(1-3):169-81. https://doi.org/10.1016/0300-483 $x(96) 03442-7$.

177. Shin HH, Jones P, Brook R, Bard R, Oliver K, Williams R. Associations between personal exposures to VOCs and alterations in cardiovascular physiology: Detroit Exposure and Aerosol Research Study (DEARS). Atmos Environ. 2015; 104:246-55. https://doi.org/10.1016/j.atmosenv.2015.01.016.

178. Lin C-Y, Lee H-L, Jung W-T, Sung F-C, Su T-C. The association between urinary levels of 1,3-butadiene metabolites, cardiovascular risk factors, microparticles, and oxidative stress products in adolescents and young adults. J Hazard Mater. 2020;396:122745. https://doi.org/10.1016/j.jhazmat.2 020.122745

179. Penn A, Snyder CA. 1,3 Butadiene, a vapor phase component of environmental tobacco smoke, accelerates arteriosclerotic plaque development. Circulation. 1996;93(3):552-7. https://doi.org/10.1161/01.cir. 93.3.552.

180. Penn A, Snyder CA. 1,3-Butadiene exposure and cardiovascular disease. Mutat Res. 2007;621:42-9. https://doi.org/10.1016/j.mrfmmm.2006.12.011.

181. Jin L, Jagatheesan G, Lynch J, Guo L, Conklin DJ. Crotonaldehyde-induced vascular relaxation and toxicity: role of endothelium and transient receptor potential ankyrin-1 (TRPA1). Toxicol Appl Pharmacol. 2020;398:115012. https://doi.org/10.1016/j.taap.2020.115012.

182. Swenberg JA, Boysen G, Georgieva N, Bird MG, Lewis RJ. Future directions in butadiene risk assessment and the role of cross-species internal dosimetry. Chem Biol Interact. 2007;166(1-3):78-83. https://doi.org/10.1016/j. cbi.2007.01.012

183. Grant RL, Haney J, Curry AL, Honeycutt M. A chronic reference value for 1,3butadiene based on an updated noncancer toxicity assessment. J Toxicol Environ Health B. 2010;13(6):460-75. https://doi.org/10.1080/10937404.201 0.499735 .

184. Albertini RJ, Sram RJ, Vacek PM, Lynch J, Rossner P, Nicklas JA, et al. Molecular epidemiological studies in 1,3-butadiene exposed Czech workers: Female-male comparisons. Chem Biol Interact. 2007;166:63-77. https://doi. org/10.1016/j.cbi.2006.07.004.

185. Willis M, Hystad P. Hazardous air pollutants and adverse birth outcomes in Portland. OR. Environ Epidemiol. 2019;3:e034. https://doi.org/10.1097/EE9. 0000000000000034.

186. Poli D, Andreoli R, Moscato L, Pelà G, de Palma G, Cavallo D, et al. The relationship between widespread pollution exposure and oxidized products of nucleic acids in seminal plasma and urine in males attending a fertility 
center. Int J Environ Res Public Health. 2020;17(6):1880. https://doi.org/10.33 90/ijerph17061880

187. Sadeghi-Yarandi M, Golbabaei F, Karimi A. Evaluation of pulmonary function and respiratory symptoms among workers exposed to 1,3-Butadiene in a petrochemical industry in Iran. Arch Environ Occup Health. 2020;75(8):48390. https://doi.org/10.1080/19338244.2020.1749018.

188. Nordlinder R, Järvholm B. Environmental exposure to gasoline and leukemia in children and young adults--an ecology study. Int Arch Occup Environ Health. 1997;70(1):57-60. https://doi.org/10.1007/s004200050186.

189. Pearson RL, Wachtel H, Ebi KL. Distance-weighted traffic density in proximity to a home is a risk factor for leukemia and other childhood cancers. J Air Waste Manag Assoc. 2000;50(2):175-80. https://doi.org/10.1080/10473289.2 000.10463998

190. Crosignani P, Tittarelli A, Borgini A, Codazzi T, Rovelli A, Porro E, et al. Childhood leukemia and road traffic: a population-based case-control study. Int J Cancer. 2004;108(4):596-9. https://doi.org/10.1002/ijc.11597.

191. Knox EG. Roads, railways, and childhood cancers. J Epidemiol Community Health. 2006;60(2):136-41. https://doi.org/10.1136/jech.2005.042036.

192. Reynolds P, Von Behren J, Gunier RB, Goldberg DE, Hertz A, Smith DF. Childhood cancer incidence rates and hazardous air pollutants in California: an exploratory analysis. Environ Health Perspect. 2003;111(4):663-8. https:// doi.org/10.1289/ehp.5986.

193. Knox EG. Childhood cancers and atmospheric carcinogens. J Epidemiol Community Health. 2005;59(2):101-5. https://doi.org/10.1136/jech.2004.021 675.

194. Knox EG. Oil combustion and childhood cancers. J Epidemiol Community Health. 2005;59(9):755-60. https://doi.org/10.1136/jech.2004.031674.

195. Whitworth KW, Symanski E, Coker AL. Childhood lymphohematopoietic cancer incidence and hazardous air pollutants in southeast Texas, 1995 2004. Environ Health Perspect. 2008;116(11):1576-80. https://doi.org/10.12 89/ehp.11593.

196. Symanski E, Tee Lewis PG, Chen T-Y, Chan W, Lai D, Ma X. Air toxics and early childhood acute lymphocytic leukemia in Texas, a population based case control study. Environ Health. 2016;15(1):70. https://doi.org/10.1186/s12 940-016-0154-8.

197. Heck JE, Park AS, Qiu J, Cockburn M, Ritz B. Risk of leukemia in relation to exposure to ambient air toxics in pregnancy and early childhood. Int J Hyg Environ Health. 2014:217(6):662-8. https://doi.org/10.1016/j.ijheh.2013.12.003.

198. Danysh HE, Mitchell LE, Zhang K, Scheurer ME, Lupo PJ. Traffic-related air pollution and the incidence of childhood central nervous system tumors: Texas, 2001-2009. Pediatr Blood Cancer. 2015;62:1572-8. https://doi.org/10.1 002/pbc.25549.

199. Danysh HE, Mitchell LE, Zhang K, Scheurer ME, Lupo PJ. Differences in environmental exposure assignment due to residential mobility among children with a central nervous system tumor: Texas, 1995-2009. J Expo Sc Environ Epidemiol. 2017;27(1):41-6. https://doi.org/10.1038/jes.2015.63.

200. von Ehrenstein OS, Heck JE, Park AS, Cockburn M, Escobedo L, Ritz B. In utero and early-life exposure to ambient air toxics and childhood brain tumors: a population-based case-control study in California, USA. Environ Health Perspect. 2016;124(7):1093-9. https://doi.org/10.1289/ehp.1408582.

201. Heck JE, Park AS, Qiu J, Cockburn M, Ritz B. Retinoblastoma and ambient exposure to air toxics in the perinatal period. J Expo Sci Environ Epidemiol. 2015:25:182-6. https://doi.org/10.1038/jes.2013.84.

202. Hall C, Heck JE, Ritz B, Cockburn M, Escobedo LA, von Ehrenstein OS. Prenatal exposure to air toxics and malignant germ cell tumors in young children. J Occup Environ Med. 2019;61(6):529-34. https://doi.org/10.1097/ JOM.0000000000001609.

203. von Ehrenstein OS, Aralis H, Cockburn M, Ritz B. In utero exposure to toxic air pollutants and risk of childhood autism. Epidemiology. 2014;25(6):851-8. https://doi.org/10.1097/EDE.0000000000000150.

204. Kuang H, Li Z, Lv X, Wu P, Tan J, Wu Q, et al. Exposure to volatile organic compounds may be associated with oxidative DNA damage-mediated childhood asthma. Ecotoxicol Environ Saf. 2021;210:111864. https://doi.org/1 0.1016/j.ecoenv.2020.111864

205. Hoffmann D, Hoffmann I, El-Bayoumy K. The less harmful cigarette: a controversial issue. A tribute to Ernst L. Wynder. Chem Res Toxicol. 2001; 14(7):767-90. https://doi.org/10.1021/tx000260u.

206. Rodgman A, Perfetti TA. The Chemical Components of Tobacco and Tobacco Smoke. 2nd ed. Boca Raton: CRC Press; 2013.

207. IARC. IARC Monographs on the Evaluation of Carcinogenic Risks to Humans, vol. 100E. France: Personal Habits and Indoor Combustions. Lyon; 2012.
208. Hecht SS. Tobacco carcinogens, their biomarkers and tobacco-induced cancer. Nat Rev Cancer. 2003;3(10):733-44. https://doi.org/10.1038/nrc1 190.

209. Fowles J, Dybing E. Application of toxicological risk assessment principles to the chemical constituents of cigarette smoke. Tob Control. 2003;12(4):42430. https://doi.org/10.1136/tc.12.4.424.

210. Lim SS, Vos T, Flaxman AD, et al. A comparative risk assessment of burden of disease and injury attributable to 67 risk factors and risk factor clusters in 21 regions, 1990-2010: a systematic analysis for the Global Burden of Disease Study 2010. Lancet. 2012;380(9859):2224-60. https://doi.org/10.101 6/S0140-6736(12)61766-8.

211. Pfeifer GP, Denissenko MF, Olivier M, Tretyakova N, Hecht SS, Hainaut P. Tobacco smoke carcinogens, DNA damage and p53 mutations in smokingassociated cancers. Oncogene. 2002;21(48):7435-51. https://doi.org/10.1038/ sj.onc.1205803.

212. Sathiakumar N, Bolaji B, Brill I, Chen L, Tipre M, Leader M, et al. 1,3Butadiene, styrene and selected outcomes among synthetic rubber polymer workers: updated exposure-response analyses. Chem Biol Interact. 2021;347: 109600. https://doi.org/10.1016/j.cbi.2021.109600.

213. Sathiakumar N, Delzell E. A follow-up study of mortality among women in the North American synthetic rubber industry. J Occup Environ Med. 2009; 51(11):1314-25. https://doi.org/10.1097/JOM.0b013e3181bd8972.

214. Sathiakumar N, Brill I, Delzell E. 1,3-Butadiene, styrene and lung cancer among synthetic rubber industry workers. J Occup Environ Med. 2009; 51(11):1326-32. https://doi.org/10.1097/JOM.0b013e3181c3c663.

215. Sathiakumar N, Delzell E, Hovinga M, Macaluso M, Julian JA, Larson R, et al. Mortality from cancer and other causes of death among synthetic rubber workers. Occup Environ Med. 1998;55(4):230-5. https://doi.org/10.1136/oem. 55.4.230.

216. Yuan J-M, Gao Y-T, Wang R, Chen M, Carmella SG, Hecht SS. Urinary levels of volatile organic carcinogen and toxicant biomarkers in relation to lung cancer development in smokers. Carcinogenesis. 2012;33(4):804-9. https:// doi.org/10.1093/carcin/bgs026.

217. Luo J, Hendryx M, Ducatman A. Association between six environmental chemicals and lung cancer incidence in the United States. J Environ Public Health. 2011;2011:463701. https://doi.org/10.1155/2011/463701.

218. Axelsson G, Barregard L, Holmberg E, Sallsten G. Cancer incidence in a petrochemical industry area in Sweden. Sci Total Environ. 2010;408(20): 4482-7. https://doi.org/10.1016/j.scitotenv.2010.06.028.

219. Park SL, Kotapati S, Wilkens LR, Tirikainen M, Murphy SE, Tretyakova N, et al. 1,3-Butadiene exposure and metabolism among Japanese American, native Hawaiian, and white smokers. Cancer Epidemiol Biomarkers Prev. 2014; 23(11):2240-9. https://doi.org/10.1158/1055-9965.EPI-14-0492.

220. Haiman CA, Stram DO, Wilkens LR, Pike MC, Kolonel LN, Henderson BE, et al. Ethnic and racial differences in the smoking-related risk of lung cancer. $N$ Engl J Med. 2006;354(4):333-42. https://doi.org/10.1056/NEJMoa033250.

221. Charbotel B, Fervers B, Droz JP. Occupational exposures in rare cancers: a critical review of the literature. Crit Rev Oncol Hematol. 2014;90(2):99-134. https://doi.org/10.1016/j.critrevonc.2013.12.004

\section{Publisher's Note}

Springer Nature remains neutral with regard to jurisdictional claims in published maps and institutional affiliations.

Ready to submit your research? Choose BMC and benefit from:

- fast, convenient online submission

- thorough peer review by experienced researchers in your field

- rapid publication on acceptance

- support for research data, including large and complex data types

- gold Open Access which fosters wider collaboration and increased citations

- maximum visibility for your research: over $100 \mathrm{M}$ website views per year

At BMC, research is always in progress.

Learn more biomedcentral.com/submissions 